\title{
CORRESPONDÊNCIA ENVIADA POR OCTÁVIO COSTA EDUARDO A MELVILLE J. HERSKOVITS'
}

\section{CORRESPONDENCE SENT BY OCTAVIO DA COSTA EDUARDO TO MELVILLE J. HERSKOVITS}

São Paulo (SP), 17 de Julho de 1943

Caro Dr. Herskovits,

Já há vários dias estou para lhe escrever, mas, infelizmente, a correria em que tenho andado em São Paulo tem sido tal a ponto de eu não ter tido nenhum vagar para coisa alguma. Minha viagem de Evanston a São Paulo, com várias paradas pelo caminho, foi bastante demorada, pois que saindo daí no dia 16 do mês passado só cheguei à cidade da garoa no dia 6 deste. No Rio estive com Dona Heloísa ${ }^{2}$ e Dr. Keer. Este deu-me suas notas ${ }^{3}$. Meu entendimento com Dona Heloisa não ficou bem assentado pois que ela deseja que um dos rapazes dela me acompanhe ao Maranhão. Ainda não lhe respondi afırmativamente, mas, parece-me, não seria de boa diplomacia dizer-lhe não, se bem que eu prefira fazer a viagem sozinho. 0 rapaz é muito moço (18 anos) e penso que vou ter algumas dificuldades com ele. Enfim, Dona Heloisa me assegura que ele é inteligente e está interessado.

Vou ao Rio na semana que vem para me entender com o Ministério da Aeronáutica ${ }^{4}$, a fim de obter prioridade para minha viagem e, nessa ocasião, direi à Dona Heloisa que concordo com uma sugestão dela. Não seria bom retardar uma resposta.

Minha situação militar ainda não está perfeitamente clara. Espero, entretanto, informar-me hoje, definitivamente, a respeito de tudo isso e só não espero novas a esse respeito para lhe comunicar agora, porque de já há muito estou retardando minhas cartas ao senhor e desejo apanhar a mala aérea do meio-dia de hoje. Mais notícias o senhor terá muito brevemente a respeito desse e outros assuntos e com detalhes. Aqui, estou-lhe dando apenas um esboço de

1. Os autores das apresentações inseriram notas informativas nas cartas enviadas por Costa Eduardo. As inclusões foram discriminadas pelas iniciais de seus respectivos prenomes e sobrenomes.

2. SF - Heloisa Alberto Torres, diretora do Museu Nacional de 1938 a 1955, manteve intensa correspondência com antropólogos e, a partir de 1934, integrou o Conselho de Fiscalização das Expedições Artísticas e Científicas do Brasil, órgão que controlava pesquisadores estrangeiros que vinham trabalhar no Brasil. Dona Heloisa guiava pesquisadores na burocracia então exigida. Cf. CORREAA, 2003; GRUPIONI, 1998. 3. RR - Até onde se pode saber, trata-se de Dr. J. Austin Kerr, vinculado à Fundação Rockefeller. Em carta datada de 16 de Junho de 1943, Herskovits escreve a ele: "This letter is to introduce Octávio Costa Eduardo, of whom I wrote you, and who will be coming out to your office to get our copy of the field notes which you have" (HERSKOVITS, BOX 27, Folder 34). Presume-se que sejam as notas de campo redigidas por Herskovits e sua esposa durante a pesquisa em Salvador, Bahia.

4. SF - Durante a Segunda Guerra homens solteiros eram recrutados no Brasil para lutar no exterior. 
notícias. 0 senhor não imagina como tenho andado aqui em São Paulo! Está tudo num alvoroço e até me sinto meio desorientado; estou ansioso para poder ir ao interior.

Minha família estava me esperando aqui em São Paulo. Infelizmente, nem todos estão bem. Minha avó tem passado mal e seu estado nos dá cuidados. Minha mãe está fazendo um tratamento rigoroso e espero que ela se reestabeleça. Todos ficaram muito contentes com minha volta e, de certa forma, parece que minha presença deu um pouco de ânimo aos pacientes. [Ciro] Berlinck e [Donald] Pierson mostraram-se satisfeitos com minha volta, também, Como vai Jean? Abraços a ela e minhas melhores lembranças à Mrs. Herskovits. Lembre-me, por favor, aos Kings, Watermanns ${ }^{5}$ e Banners.

Um grande abraço do amigo e discípulo, Octávio Costa Eduardo.

Bebedouro (SP), 22 de setembro de 1943

Carta $n^{\circ} 2$

Caro Dr. Herskovits,

Acabo de receber um telegrama de São Paulo, comunicando-me a remessa feita pelo senhor de oito mil e seiscentos cruzeiros para a viagem ao Maranhão. Esta quantia, acredito, cobrirá as despesas de viagem do Rio a São Luís, ida e volta (Dona Heloisa conseguiu com a Panair a redução de 50\% no preço da passagem), bem como as minhas despesas nos três ou quatro próximos meses. Recebi também sua carta datada de dois de setembro, em que o senhor acusava o recebimento de minha carta de 12 de julho. Até parece incrivel que uma carta aérea tenha demorado cinquenta dias para chegar às suas mãos. Fiquei francamente surpreendido e...zangado. Alegrou-me imensamente receber notícias suas e de seus bons amigos da Northwestern University. Confesso-lhe estava ansioso pela falta de notícias suas. Não contei com atraso das minhas cartas. A propósito, espero que o senhor tenha recebido minha segunda carta, enviada aqui de Bebedouro, nos primeiros dias de agosto. Nela, eu lhe pedia para enviar o dinheiro para a viagem (quinhentos dólares, porque eu não sabia ao certo se conseguiria a redução no preço da passagem), para a Escola de Sociologia, esquecendo-me, entretanto, de lhe indicar um banco através da qual o cheque poderia ser remetido. Espero, porém, que isto não tenha constituído uma fonte de atrapalhações para o senhor. Há cerca de duas semanas, diante da falta de notícias, estive em São Paulo e de lá enviei-lhe um cabograma por intermédio do Consulado Norte-Americano. Não tinha naquela ocasião recebido sua carta. Nessa mesma época, fiz os arranjos preliminares para minha partida do Rio. Meu irmão, em São Paulo, e Dona Heloisa, no Rio, estão providenciando para que me seja possível partir do dia 3 a 5 de outubro. Como eu tinha planejado estar em São Luís antes do dia 15 deste mês, o mais tardar no dia 20, terei perdido cerca de 20 dias. Espero, porém, que trabalhando bastante, o tempo perdido seja recuperado. Estou bastante ansioso para começar e tenho muitas esperanças de que serei bemsucedido. Dona Heloisa informou-me há dias que o rapaz do Museu não poderá seguir comigo, o que, entre nós, e muito veladamente, me alegrou bastante!

Minha estada aqui no interior tem sido muito agradável (minha família nunca me mimou tanto), ao mesmo tempo que tem sido muito útil do ponto de vista etnográfico. A vida de uma cidade pequena, considerada do ângulo de um residente, é uma coisa, mas vista do ângulo de alguém que aí viveu por muito tempo e depois se ausentou para obter um treino em antropologia

5. RR - Trata-se de Richard Alan Waterman (1914-1971), aluno e discípulo de Melville J. Herskovits, especialista em etnomusicologia, e professor no Departamento de Antropologia da Northwestern University. 
e viajou um bocado, é uma coisa bem diferente. Os mexericos, as intrigas, os comentários na esquina do café, os bailes, o footing (das 7 1/2 às 9 da noite diariamente, as moças passeiam de um lado para outro diante da Praça da Matriz, no ponto central da cidade, e os rapazes nas calçadas ficam a comentar as graças daquela ou a falta de compostura dessa outra e assim por diante - isto é que uma explicação longa de footing) até a maneira de namorar, tudo enfım constitui para o outsider ou para quem de alguma forma se tornou um outsider uma fonte riquíssima de informações. Não é de se estranhar pois eu esteja me divertindo tanto e achando minha estada aqui tão interessante como lhe estou contando. Quanto o meu trabalho, tenho ambas as traduções, a do seu artigo e a de minha tese terminadas, só faltando datilografá-las e poli-las um pouco mais, esta segunda parte dependendo da primeira.

Infelizmente máquina de escrever que esteja desocupada é aqui, como se diz com humorismo, manga de colete. Fiquei satisfeito por saber que Vianna Moog finalmente apareceu e que se está dando bem por aí (pudera na sua companhia) e que teremos, quando ele voltar, um livro interessante e com cerne sobre os Estados Unidos. Pena ele não ter aparecido antes porque eu bem gostaria de tê-lo conhecido. Presumo que o senhor, Tames King e Dick já estejam se preparando para o novo ano académico. Dick, então, vai para Washington? Só lhe fazem justiça pelo magnífico trabalho que ele está fazendo. Espero que Bascom ${ }^{6}$ tenha se refeito do ataque de malária. Os Bauers ${ }^{7}$ devem estar ocupados com Linda e os King com Topper, meu sempre lembrado sobrinho. Estou para escrever a eles todos e fá-lo-ei qualquer desses dias. Se lhe perguntarem por mim, diga-lhes que continuo vivo e que tenho saudades da turma toda, a quem envio muitos abraços. Bons dias os que passei aí!

E Mrs. Herskovtis e Jean, como vão? Aposto que Mrs. Herskovits é agora senhora de uma boa colheita, do victory-garden, de espigas de milho, não é? Meus planos de trabalho são os mesmos que tinha quando sair daí. Os três primeiros meses vou passá-los em São Luís. Quanto a detalhes, só quando estiver lá mesmo é que lhe poderei informar de alguma coisa. Levo cartas ${ }^{8}$ de Dona Heloisa para o Interventor e alguns grossos de lá. De um amigo de meu pai levo uma carta para o diretor da Saúde Pública do Maranhão, um primo deste senhor. Hospedar-me-ei, até me ambientar, no Grande Hotel de São Luís e depois verei que rumo tomo. Creio que o senhor pode escrever-me para lá, se houver necessidade ou mesmo que não haja. Espero poder escrever-lhe antes da minha partida do Rio e então lhe darei meu endereço certo em São Luís. Fico-lhe grato pela remessa do dinheiro ${ }^{9}$ e sinto que o atraso das minhas cartas lhe tenha causado aborrecimentos.

À espera de notícias, aqui vai um abraço, à brasileira, do discípulo e amigo, Octávio Eduardo.

6. RR - Referência a William Russel Bascom (1912-1981), especialista em Nigéria, professor no Departamento de Antropologia da Northwestern.

7. RR - Referência ao casal Raymond A. Bauer e Alice H. Bauer, alunos de Melville J. Herskovits no Departamento de Antropologia da Northwestern University.

8. SF - Obviamente as cartas de apresentação do pesquisador às autoridades do lugar são importantes e indispensáveis para o bom andamento do trabalho de campo.

9. SF - Esta preocupação aparece várias vezes na correspondência. É curioso que na época o orientador é que remetia o dinheiro ao orientando que vivia da bolsa de estudos. 
São Luís (MA), 1 de Novembro de 1943

Carta $n^{\circ} 3$

Meu caro Dr. Herskovits,

Finalmente cheguei ao meu destino. Já não era sem tempo. Uma série de circunstâncias, as duas últimas das quais foram uma informação falsa do agente na Panair e uma colite que, infelizmente, ainda me aflige um pouco, me atrasaram bastante. Espero, entretanto, trabalhar com muita persistência e recuperar o tempo perdido. Na verdade, já comecei a trabalhar. Estou nesta muito interessante e pitoresca cidade há menos de 8 horas e já visitei um terreiro de mina, nome dado aqui ao candomblé. Fui ontem, domingo, à noite.

Sai do Rio no dia 26 de madrugada. Parei uns dias na Bahia, onde estive com o Dr. Thales de Azevedo, e até fiz uma pequena exposição à classe dele de antropologia, com o diretor do Instituto do Cacau. Fiz nova parada em Fortaleza por 3 dias à espera de avião. Só dia 30 à noite cheguei a São Luís. Esta é uma cidade de um pitoresco todo especial. Situada num sítio suavemente ondulado, de ruas estreitas e casas velhas coloniais, esta é uma cidade do século XIX. Agrada à vista.

Hospedei-me no Hotel Central, mas não creio que permanecerei aqui por muito tempo. Em todo caso, meu endereço permanente será Semta (Serviço Especial de Mobilização de Trabalhadores para a Amazônia), que é dirigido por um amigo meu de São Paulo. A abreviação é o bastante. Encontrei-me aqui com o Dr. Antônio Lopes ${ }^{10}$, pessoa que se tem interessado pelo negro e feito observações a respeito da vida destes. Parece-me ser boa pessoa e muito bem intencionada. Surpreendeu-me a agudeza de algumas das suas reflexões. Assim, por exemplo, criticou as conclusões de [Arthur] Ramos sobre o substratum histérico das possessões e sua explicação da origem do bumba-meu-boi, que ele pensa ser sertanejo e não africano, é também bem feita. Ontem fui com ele a um terreiro de mina muito afastado da cidade, uma distância de 9 quilómetros, num bairro chamado do Anil. Apresentou-me à mãe do terreiro, também chamado tambor de mina, mas não se demorou lá. Fiquei entregue a mim mesmo, o que foi ótimo porque pude não apenas ver a dança, mas também conversar com algumas dançantes (ajós), com a mãe do terreiro e alguns homens, possivelmente ogãns. "Meu terreiro é nagô", disse-me a mãe de santo, no que aliás foi confirmada por outros informantes. "Minha mãe fundou este terreiro, ela foi feita por nagôs vindas da África mesma. Nós, Nagôs, não comemos como os Jêjes. Estes comem na quaresma. 0 alimento dum nagô é um charuto, um leite, e só”. 0 culto é, evidentemente, uma mistura Jejê-Nagô, embora poucas canções africanas tenham sido cantadas. Ouvi nomes de divindades yorubás e daomeanas nas canções. Assim, "Eperé Garapé" a que o coro respondia vodum; “Oh Bade, oh Bade, oh senhor Bade, etc. Elegua”, a que o coro respondia: "Paré, Oh gente, cadê seu Legua, Ele foi beber/ Tá no mar/Carará cum seu mo nagô/ Cada um cum seu orixá".

Também ouvi os nomes de Cosme Damião, São Benedito e Verekete. As canções a Legua (Elegbara, sem dúvida) foram, fato interessante, cantadas quase no fim da festa (Peço-lhe mil desculpas por ter que escrever nas cartas, mas não há papel no hotel e, hoje, Dia de Todos os Santos, o comércio está fechado).

10. SF - Intelectual maranhense interessado em negro, religião e cultura popular. Costa Eduardo o encontrou assim que chegou a São Luís e foi por ele levado a um terreiro de mina na periferia da cidade, onde pela primeira vez observou um toque de tambor de mina que a seguir descreve ao orientador com muitos detalhes e grande acuidade. 
Um rapaz de 25 anos presumivelmente, caboclo, residente neste terreiro, talvez um ogã, disse-me: "O senhor deveria ver este terreiro no tempo da velha. Ela morreu há dois anos. Com estes braços eu tirei ela daqui. Era uma briga porque todo mundo queria carregar o caixão. Ela costumava ficar sentada aqui (um barracão a uns oito metros do terreiro) e quando eles erravam, ela via logo". Parece, o que algumas dançantes confirmaram, que este terreiro tinha grande prestígio antes. Mas, aqui estou eu a lhe falar sobre tudo isto, sem lhe dizer a disposição das casas e o número de pessoas presentes. 0 terreiro fica a uns 400 metros da linha de bonde. Na entrada, há duas casas separadas uma da outra por um corredor de um metro de largura. A que está à esquerda de quem entra, possui um puxado nos fundos (como a outra) em que se encontra uma longa mesa. A um canto estavam três atabaques, um deles enorme de metro e pouco de comprimento com um raio de uns 20 centímetros, e os outros dois de uns 10 centímetros é raio de uns 10 ou 12. Logo após o puxado, está o terreiro propriamente dito. Mais ou menos 12 metros de comprimento por 6 de largura. Cercado por paredes de uns 60 centímetros de altura. A parede do fundo de uns 2 metros e meio. Aí, no fundo, fica um altar; à frente um candelabro; uma vela acesa. Isto numa prateleira. Noutra, mais acima, dois vasos grandes de metal, com flores, no meio dos quais está um vaso pequeno. Na parede, que une uma prateleira à outra, está escrito Salve São Benedito. Numa terceira prateleira, duas imagens de santos. Pareceram-me ser Santo Antônio e São Benedito. 0 altar está bem no meio da parede do fundo, de um e outro lado estão penduradas litogravuras de Santos, oito ao todo. De um e outro lado do altar, estão dois tambores, um de cada lado, colocados horizontalmente; são chamados tambores de mina. Do lado esquerdo de quem olha o altar de frente, estão quatro pessoas, homens, às vezes um deles é substituído por uma mulher, adulta ou menina, tocando cabaças. Duas delas são enormes. 0 que tem a maior fica bem junto ao altar. Há bancos de madeira ao redor de todo o terreiro que é coberto por sapé. Cobertura resistente. Sentadas nos bancos e debruçadas sobre as paredes, umas 100 pessoas. Todos olham a dança com interesse, alguns parecem não compreender do que se trata. Às vezes, conversam. Gente de idades várias, meninas e meninos, moças e moços, adultos.

A dança é uma coisa admirável; há 14 dançantes no auge da "vadiação". Infelizmente, não tenho papel para descrever-lhe tudo. Há duas espécies de canções: "doutrina de cura" e "doutrina de mina". As moças da casa usam saia amarela e blusa branca. Cobrindo a saia, uma faixa branca, muito bem trabalhada. Há 3 ou 4 visitantes. Muitas vezes cantam em falsete; pelo menos, assim penso.

No quintal há três pequenas casas no fundo e mais dois puxados cobertos ${ }^{11}$.

0 terreiro tem a mãe do terreiro, a guia do terreiro, que dá apó e ormim (água, parece), aquele num pires e este numa cuia, às dançantes (para fortalecer o vodum, disse-me uma dançante) e uma contra-mestre (? a verificar). Bem, aqui tenho que terminar. Hoje, há lá outro terreiro e obtive licença para voltar. Hoje, cheguei ao hotel às 6:30 da manhã. Dormi um bocado numa rede, das 3:30 às 5:00. Espero suas notícias e conselhos. Lembranças minhas à Mrs. Herskovits e Jean.

Um abraço afetuoso do Octávio ${ }^{12}$.

11. SF - Tendo chegado há oito horas a São Luís, Costa Eduardo observa e descreve o toque, as danças, o espaço físico, a decoração, os nomes das entidades, etc., demonstrando a qualidade de sua formação como excelente etnólogo. Em apenas uma visita, é impressionante os dados que conseguiu anotar.

12. RR - Em carta datada de 20 de novembro de 1943, Herskovits responde: "I suggest that you find out what alternatives there are for the phrase 'terreiro de mina' and particularly investigate what the people know about this word "mina". I am not all convinced that it derives from the Gold Coast, and you may be able to 
São Luís (MA), 13 de Novembro de 1943

Carta $n^{\circ} 4$

Meu caro Dr. Herskovits,

Faz duas semanas hoje que cheguei a São Luís. Daqui escrevi-lhe logo após a minha chegada; espero que tenha recebido esta carta. Nela eu lhe dava as minhas primeiras e apressadas impressões da cidade e de uma cerimônia a que tinha assistido. 0 número de terreiros de mina na Ilha de São Luís é grande. Encontra-se a maioria absoluta deles nos subúrbios, muitos deles afastados da linha de bonde. Infelizmente porque o chefe de polícia está ausente, ainda não consegui uma lista dos terreiros. Para funcionar, os terceiros têm, como na Bahia, de obter licença. Um dos meus melhores informantes, um rapaz preto, de 26 anos, enumerou-me 20 terreiros, de que, no momento, ele se lembrava, mais há mais. Desses vinte, três ou quatro estavam antes localizados num dos bairros da cidade, mas tiveram de se mudar para mais longe da cidade, parece que por causa da intervenção da polícia. Entre os 20 terreiros enumerados, quatro foram assentados nos três últimos anos. Este fato, segundo me parece, é bem interessante e significativo. 0 estudo destes terrenos possivelmente indicará uma tendência no sentido da sua maior aceitação, mas ainda é cedo para fazer esta afirmação. Estou estabelecendo os contatos que posso. Infelizmente, o transporte é um problema. 0 bonde fica bem aquém dos terreiros, pelo menos na maioria deles, e os automóveis não tem gasolina para fazer longas viagens ou desejam uma fortuna. Entretanto, isso não tem sido uma dificuldade sem solução. Vou fazendo o que posso. Na cidade, há dois terreiros: são a Casa das Minas Jêje e a Casa de Nagô. São as mais antigas e, parece, as que menos têm sofrido a influência das crenças de origem indígena. Já estabeleci contato com os dois, principalmente com a Casa das Minas Jêje. Esta é uma fraternidade fechada. Ainda não houve lá nenhuma cerimônia, mas é do meu conhecimento que as vodunsi só cantam em Jêje. 0 padrão africano de organização das divindades em famílias é mantido. As três famílias são as de Davisse ou Dahomé; Danbirá (Odan, cobra) e Badé. 0 sincretismo afro-católico se verifica nesse terreiro bem como nos outros. Uma explicação interessante foi dada por uma filha de santo Jêje. Referindo-se a Santa Bárbara, disse: "Como santa, está lá em cima, é Santa Bárbara, mas como mistério ela é vodun, ela é Sobô”. Note o uso da expressão mistério. Ainda não consegui muitos dados sobre a identificação das divindades católicas com os deuses africanos. Parece que há uma certa relutância em revelar as correspondências. Noutros casos tenho a impressão de que

get some significant information about the matter. 'Legua' is, of course, the same as 'Legba'. However, the latter is the pronunciation of the Dahomeans who live in the northern part of the old kingdom about Abomay while 'Legua' is the pronunciation given the name of the deity near the coast about Whydah. That the songs for this deity could come near the end of the ceremony is most unusual and will, of course, get after that particular deviation from custom elsewhere. Your description of the cult house was most interesting, particularly the fact that the altar was in full view, and that the men who played the calabashes sat next to it. Of course, this was your first visit, and I take it that there were parts of the house you did not see. I would be most striking if this altar in full view were the principal one, and if the house did not have a room with the shrines of the gods after the manner of the Bahian peji. When you speak of these men playing calabashes, I suppose you mean that they were being played in place of the drums. Does this mean that the use of the drums is forbidden except, as in Bahia, with special permission? If that is the case, you will be able to work a beautiful 'lead' by becoming friendly with the proper authorities, explaining your research to them and getting their cooperation to make it possible for you to obtain permission for the cult house to use drums when they need them. Of course, if the calabashes were by any chance the Yoruban type that have shells on the outside, that would make it even more interesting” (HERSKOVITS, BOX 27, Folder 34). 
há ignorância a este respeito. Voltando as Minas Jêjes, como lhe pode interessar, enumero os membros que já conheço das três famílias. À família de Davisse, pertencem Agongono, Dako, Bedigar e Tossá-Tossé (Cosme e Damião). À de Danbirá pertencem: Sapatá, que é pai de Podibeji e Bôssa, e Boassalabê, marido e mulher. Sobô e Alanto pertencem à família de Badé. 0 pai de todos é Dadarrô; Zomadono, que é o segundo pai, pertence ao panteão de Davisse.

Na Casa de Nagô conhecem todas, ou a maior parte me parece, das divindades iorubás. Nesta casa fazem o despacho de Leba ou Lebara, também conhecido por Exú, o que não parece ser o caso nas outras casas, nem no terreiro Jêje.

Quanto à influência da religião noutros aspectos da vida cultural, não sei ainda muito. Quando uma filha de santo morre há um tambor-de-choro. Um ano mais tarde há outro. Uma filha de santo só se casa depois de obter a licença do seu vodum, me disseram na casa Jêje. As pessoas doentes acorrem muitas vezes às mães de santo, embora elas, ao que parece, não sejam curadoras. Curadores são os pajés, os que trabalham com cura. Às festas destes dá-se o nome de pajelança também. É de origem índia, mas a mistura com elementos da religião católica enorme. Qual a parte desempenhada por elementos do culto africano, ainda não sei, mas suspeito que sempre haverá alguma coisa. No sábado passado assisti a uma cura (o nome macumba ou feitiçaria também foi mencionado). Era apenas para festejar o invisível do Pajé. Não houve cura propriamente dita. Quando há, os pajés tiram, segundo se acredita, alfınetes, agulhas, baratas, bichos, do corpo das pessoas que são vítimas de malefícios.

Não sei se este amontoado de dados lhe dirá muito sobre a vida dos pretos em São Luís ${ }^{13}$. Eu mesmo ainda estou meio incerto sobre a situação, mas não há dúvida de que aculturação aqui foi muito mais intensa do que na Bahia. 0 que domina, parece, são os cultos caboclos, embora se diga que trabalham na linha nagô. Em nenhum dos terreiros vi até agora altares para as divindades. Os pejis naturalmente existem. Moro com um amigo meu, Paes Loureiro, Superintendente do Semta, no prédio em que este está instalado. Temos cozinheira e servente, ambos dos quais têm sido bons informantes.

Acho o trabalho extremamente interessante e estou bastante animado e com esperanças.

Gostaria de receber notícias suas. Por favor, dê lembranças a Mrs. Herskovits e abraços a Jean. Na próxima carta, der-lhe-ei alguma coisa sobre as possibilidades no interior.

Um abraço bem brasileiro do Octávio

Nota: a mistura racial aqui foi formidável. Não será isto um dos fatores responsáveis pela aculturação ${ }^{14}$

13. SF - Nesta correspondência de 13 de novembro constamos que, duas semanas após sua chegada, Costa Eduardo apresenta ao orientador uma visão geral sobre os terreiros da periferia e do centro da cidade e já estabelece contatos com a Casa das Minas e a Casa de Nagô, conhece a organização das entidades, nome e parentesco dos principais voduns da casa jeje, diferenças entre tambor de mina e cura ou pajelança da qual já assistiu cerimônia e faz relações entre sincretismo e aculturação. Discute sobre a ausência ou presença de Legba. Tendo em vista o fechamento e reservas da comunidade, em pouco tempo o pesquisador conseguiu informações fundamentais. Além do fato de Costa Eduardo já ter experiência como etnólogo, talvez por ser um jovem pesquisador vindo de fora com apenas 24 anos tenha estimulado as velhas vodunsis a adotá-lo como filho e a conversar sobre coisas da religião delas que muito o interessavam.

14. RR - Em sua resposta, datada de 8 de Dezembro de 1943, Herskovits comenta: "It is apparent that you have an enormous amount of Dahomean survivals, and the list of names of santos you gave me has a number of Dahomean beings that never come on in the New World, either in my own work, or in the literature, as far as the New World is concerned. Agongono, Dako, Zomadono, are all names of early Dahomean royal figures. Dada was the name of the king, and Dandarro is, I imagine, Dada Aho, also a royal designation. I 
São Luís (MA), 27 de novembro de 1943

Carta $n^{\circ} 5$

Caro Dr. Herskovits,

Espero que o senhor tenha recebido minhas cartas anteriores de São Luís, em que lhe informava sobre o andamento de meu trabalho aqui. Em minha última carta, eu lhe prometi dizer alguma coisa sobre os lugares no interior mais indicados para eu ir. Inicialmente, devo dizer que ainda não tomei nenhuma resolução e gostaria de receber suas sugestões. Conversando aqui com várias pessoas foi-me dito que na região de Viana, ao longo do Rio Pindaré, a oeste de São Luís, há pequenos agrupamentos habitados somente por pretos. Esta região sofreu grandemente a influência indígena. Ao sudoeste de São Luís, na estrada de ferro São Luis-Teresina, localizase a cidade de Codó, que foi um dos pontos de concentração de escravos do estado e, segundo consta, há lá um ou dois terreiros-de-mina. Esta cidade fica perto da segunda cidade, do estado do Maranhão, Caxias. Para o lado do Pará, consta que na região de Guimarães, existe uma grande porção de negros. Não se sabe se há lá terreiros, mas é certo que a região é rica de curadores. Aliás, a impressão que tenho colhido é que a pajelança de origem indígena domina no interior todo. Estas são até agora, em suma, as informações que tenho. Espero indagar melhor e oportunamente lhe escreverei a esse respeito.

0 trabalho aqui em São Luís está sendo conduzido proveitosamente alguns dias enquanto outros dias não colho tanto material quanto desejaria. Confesso-lhe que tenho tido dificuldades muitas vezes em obter informações embora tenha estabelecido contato com meus informantes. Isto se aplica principalmente à Casa Nagô de que já falei. A mãe-de-terreiro está sempre ausente. Na casa, moram mais 5 ou 6 iniciadas, toda de idade, mas dessas só uma até agora se dispôs a falar e, como está muito velha, anda muito esquecida. Outra dificuldade é que nas casas-de-terreiro nunca, ou sendo menos exagerado, há poucas oportunidades de se conversar particularmente com um só informante. As filhas-de-santo estão sempre juntas, e mais alguém, de forma que é uma dificuldade conduzir a conversação para onde eu quero. Todavia, não estou desanimado e aos poucos vou colhendo meus dados.

Tenho obtido informações interessantes sobre a vida da família. Casamento não é muito comum. As relações de amasia (estou criando o termo) imperam. Em muitos casos, nota-se a ausência do homem que provê a família. É comuníssimo entregar os filhos para os avós, padrinhos ou outras pessoas para criar. Relações múltiplas não são admitidas pelas mulheres casadas, e, até agora, não percebi nenhuma sanção de ordem religiosa que fortaleça ou sustente a família.

Este material (tenho procurado obter quer diretamente ou por terceiros histórias de famílias), me parece, oferece um contraste interessante com o da Bahia. A distinção entre moça (virgem) e solteira (não-virgem) é aqui feita.

Os dados sobre funeral ainda não são muitos mas sei que quando morre alguém que não pertence ao culto costuma-se contar histórias durante a vigília do corpo. Há também

would advise that for the time being you concentrate on the cult groups in the town, at the same time pursuing inquiries as to a good center in the country back of the town to continue later with your research. I should say that the Jêje house might be your central point of focus. I would simply be about, not asking direct questions, but from time to time leading the conversation into lines in which you can contribute in such a way as to indicate that you know more than you are telling. I do not know whether or not you have a copy of our memoir on Dahomean religion, but since it should be of considerable help to you, I have asked the Anthropological Association to send you one” (HERSKOVITS, BOX 27, Folder 34). 
passatempos outros, brinquedos de casamento, por exemplo, cuja essência é profana. Não há sihun nos cultos (só tambor-de-choro) mas, por ocasião da morte de um curador, os outros membros da "cura" têm como preceito rezar à noite por oito dias e só então o espírito do morto se retira. Isto me foi dito por um curador e, naturalmente, necessita de confirmação.

Quanto a sociedades, com exceção de uma sociedade funerária, que açambarcou várias outras que havia, parece que não há nenhuma outra. Esta é muito popular.

Como o senhor pode ver, embora estas informações que lhe dou tão secas, vou obtendo minhas informaçõezinhas e creio que aos poucos vou ganhando uma ideia adequada da vida da gente que estou estudando. Estou ansioso, entretanto, por receber sugestões suas.

Afora meus contatos com os meus pesquisados, vi ontem o Interventor Federal, a quem pedi para me apresentar ao chefe de polícia para me pôr a par das licenças concedidas.

Quanto aos documentos históricos, espero em breve examinar os arquivos da Alfândega à procura de dados sobre a proveniência dos escravos que para aqui vieram.

Faço meus votos para que o senhor esteja tendo um agradável ano letivo e não tão trabalhoso como o ano passado. E o livro sobre a Bahia, quando o teremos? Lendo e relendo quase que diariamente suas notas e de Mrs. Herskovits não apenas sinto inveja da eficiência de ambos como "field-workers", mas me abismo ante a riqueza do material.

Minhas melhores lembranças a Mrs. Herskovits e Jean. Lembranças também, por favor, aos Kings, Bauers e Watermanns.

À espera de notícias suas abraço-o cordialmente o aluno e amigo, Octávio ${ }^{15}$.

São Luís (MA), 10 de dezembro de 1943

Carta $n^{\circ} 6$

Meu caro Dr. Herskovits,

Estou já há dias para responder sua carta de 20 de novembro. Não fiz antes porque recebi notícia de meu pai que havia uma carta sua para mim em Bebedouro. Meu pai já me enviou esta carta, mas, até agora, não a recebi. Embora não possa respondê-la, posso ao menos dizerlhe que chegou. Assim, passo a responder-lhe a carta do dia 20 e dar-lhe mais algumas notícias sobre meu trabalho.

A alternativa para terreiro de mina é tambor de mina, ou, simplesmente, mina. Esta palavra não tem absolutamente nenhuma relação com a Costa do Ouro. Minas ou contrabanda é a palavra geral para os africanos que vieram para cá como escravos. Assim, diz-se mina jêje, mina nagô, mina cambinda, mina angola, mina fulupa. Mina ashanti é um termo, ao que parece, desconhecido. Penso poder afırmar que os negros para cá trazidos vieram principalmente da terra dos iorubás e do Dahomei. 0 conhecimento pelas minhas informantes dos termos acima sugere que os negros cambindas e angolas também entraram. A mãe de terreiro da Casa de

15. RR - Em resposta despachada em 18 de Dezembro de 1943, Herskovits pondera: "It seems to me that as regards work in the interior, it would be a good idea to make Caxias your base. Of course, the region of Guimarães sounds good, if it does not present too many practical difficulties in comparison with the former site. I do not feel that the eastern part of the state, near Vianna would be as rewarding, from what you say. As regards the problem of Indian-African acculturation, while I feel that for the present field-trip the problem of African survivals in a milieu of European derivation offers quite enough to do, and your emphasis should be on this problem, yet if the other influence is also present, it should not to be too difficult for you to include it in your program" (HERSKOVITS, BOX 27, Folder 34). 
Nagô diz ser neta de Angola. A mãe de terreiro da Casa dos Jêjes, Mãe Andreza, que tem mais de 70 anos, penso, lembra-se de ter visto na sua meninice um tambor de mina cambinda. Além disso, anteontem, dia 8, ouvi canções, numa festa que lá se realizou, que um dos tocadores de tambor chamou cambinda. 0 ritmo aproxima-se bastante do de batucada ou samba e a maneira de dançar lembra o samba. Numa das minhas cartas anteriores, descrevi-lhe em geral a situação aqui quanto à conservação das crenças e práticas religiosas africanas e sua mistura com crenças católicas e indígenas. Penso poder agora ampliar este quadro. A única casa que realmente guarda os padrões africanos é a Casa das Jêjes. Isto é tacitamente reconhecido pois que a casa é denominada Casa das Minas, denotando a preservação da tradição africana. Desde os nomes dos instrumentos até a teologia, tudo é daomeano. Senão vejamos: os tambores são ocos, de uma só boca, sendo o couro mantido por calços de madeira. A orquestra é constituída por três e mais o ferro e duas ou três cabeças. 0 tambor maior é o [hum], o médio é o [gumpli] e o menor é o [rumpli]. 0 tocador é chamado [humto]. 0 maior é batido com a mão esquerda e uma varinha resistente que termina num gancho, chamada [agudávi]. Os outros dois são batidos com as varinhas, podendo o médio ser batido com a mão também. 0 tocador do [hum] toca com a varinha ora na boca, ora no corpo do tambor. 0 ferro é chamado [gã] e a pessoa que toca, uma mulher, é a [ganto]. A cabaça é o [sekjere]. Os músicos são excelentes e o ritmo é alguma coisa que eu nunca tinha ouvido antes. Eu penso que é imprescindivel fazer algumas gravações e já escrevi a Dona Heloísa para ver se ela me pode arranjar um cilindro ${ }^{16}$.

Como no Rio Grande, o culto aqui não tem ogãns. Suspeito, pois, que os tocadores tenham uma função importante, mas até agora pouco me adiantei a este respeito. Estou ansioso para receber seu trabalho sobre o papel dos tocadores de tambor e estou certo de que me será de grande utilidade.

Quanto à teologia, o padrão daomeano é aqui mantido, embora haja omissões ou modificações. As divindades, voduns, se organizam em três grandes famílias: a de Davisse, a de Dambirá e a de [Kevioso]. Chefe de todos é [Dada'ho]. Sua mulher é Naiadona e seu filho [Koisinakaba]. Zomadonu é filho deste, e, portanto, neto de [Dada'ho]. Este, porque muito velho, entregou o governo a Zomadonu, que é o chefe da família de Davisse.

Zomadonu é solteiro. São seus irmãos Agongono, Zacá e Dossú e, ao que parece, são também conhecidos como Vavaluno. ${ }^{17}$ Ainda não sei quais são suas atribuições.

0 chefe da família de Dambirá é Zapatá mas ele não baixa. Baixam seus filhos: Pódeboji, Lepon, Alôgne, [Hueji], Bossa [mulher], Bajono, Abojú, Abolotoê, Bossucó,e Ewá (mulher), a qual agora mora com os nagôs. Esta família ou nação tem as atribuições do chefe: dar e tirar bexigas, conforme o procedimento das pessoas.

À família de Kevióso pertencem Sobó, solteira e velha, que criou Kevióso e Badé e Averekete, Loko, [Lisá], Avejó, Agantó, Abê (mulher). Esta família toma conta dos trovões, das chuvas, das águas do mar. Sobó e Badé encarregam-se dos trovões e da chuva. Abê toma conta das águas do mar.

Os mesmos Kevi'oso, quando em ninos, são chamados [Tohueno]. 0 “rei” deles é [Hurand'dolo]. Inclui Apojovó, Tossá-Tossé (Cosme e Damião), Bossú, Apojé, Nanin, Dossupé.

Em cada uma das famílias, há um vodum que, sendo o mais moço, é "mais dengoso", na expressão de Mãe Andreza. Tem uma irmã para acobertá-lo e protegê-lo da zanga do pai. Na família de Dambirá, Bossucó, o mais peralta, é protegido por Bôssa. Tossá é o mais “dengoso"

16. SF - Costa Eduardo tenta conseguir aparelho e material para gravar os toques que o encantaram.

17. SF - 0 nome correto é Savaluno. 
da família de Davisse (uma pequena incoerência em se tratando dos panteões). Finalmente, Averekete é o mais voluntarioso da família de Kevio'so, tendo como seu protetor Abê.

Será necessário algum comentário?

Penso que não. Só aos poucos fui obtendo estas informações e confesso-lhe que não foi fácil. Os pretos são hábeis em esquivar-se a perguntas; simplesmente dizem que não sabem ${ }^{18}$. Quanto ao grau de parentesco exato das divindades, ao que parece, eles próprios não sabem pois que a resposta, mesmo quando dada com sinceridade e honestidade, é são parentes.

Leba é desconhecido dos Jêjes. Ontem, descobri que antigamente elas faziam o sacrifício de galo ou galinha para [Hunu'co] e o depositavam nas encruzilhadas. Não o fazem mais, disse Mãe Andreza, por causa da atitude do povo. Que diriam se vissem alguém ou soubessem de alguém das Casas das Minas depositando uma galinha numa encruzilhada senão que era [coyo'yo], isto é, feitiço ou "coisa feita”? Esta foi a maneira pela qual ela me explicou a questão. Mas despacha-se [Hunu'co] jogando-se água no tempo, isto é, para o ar. De outra forma, ele viria atrapalhar o brinquedo. Também não comento isto. 0 senhor pode fazê-lo o melhor ${ }^{19}$.

Houve quatro dias de festas na Casa das Minas, dias 4, 5 e 6 e 8 deste. 0 máximo número de vodunsi era 15 ou 16, mas há mais. A assistência, nunca maior do que 100 pessoas nos dias mais animados, não compreende nada do que se está passando, a não ser que as vodunsi estão possuídas; admiram a dança e a música. As canções, ninguém compreende, porque são todas em Jêje (eu mencionei fon, mas na casa dizem Jêje). As canções e as danças são dramatizadas e constituem, sem dúvida, grande teatro. Estou certo de que o senhor e Mrs. Herskovits apreciariam muitíssimo. As canções em nagô são poucas e a maioria delas é em português. Há linhas de nagô, caboclo, do mar, gentil (africano, segundo a mãe de terreiro da Casa de Nagô). Os nomes dos "encantados" são na sua maioria portuguesíssimos. Nomes indígenas há demais. Os tambores destas casas são de duas bocas ${ }^{20}$.

A possessão é aqui uma coisa institucionalizada ao extremo. Nem parece que as vodunsi estão possessas. Falam com a gente, fazendo perguntas de cortesia, abraçam, etc. Respeitam-nas muitíssimo ${ }^{21}$.

Penso que me exprimi mal no tocante ao uso dos tambores na minha primeira carta. 0 uso deles aqui é livre.

Tenho visto Dr. Antonio Lopes poucas vezes. Ele ficou lisonjeado com o trecho da carta em que o senhor se refere a ele e pediu-me para lhe agradecer. Gostaria de ter suas publicações. Conversando com ele sobre o termo mina, ele disse que leu em algum lugar que este termo deriva da Feitoria das Minas, um entreposto de embarque de escravos na África. Tenho me dado muito bem com um médico, Dr. Teixeira, muito lido e de mente aberta. Temos trocado

18. SF - Com grande margem de precisão, Costa Eduardo, pouco mais de um mês após chegar a São Luís, conhecia o nome e parentescos de quase todos os vodun da Casa das Minas.

19. SF - As informações que apresenta sobre a ausência de Légua são importantes e difíceis de serem conseguidas.

20. SF - Tendo assistido apenas a poucos rituais em pouco tempo deve-se destacar que Costa Eduardo conseguiu informações fundamentais com detalhes importantes sobre as divindades cultuadas na casa jeje. Apresenta com precisão nome das divindades, relações de parentesco, características do transe das vodunsis, número de vodus presentes aos rituais, regras de cortesia, papel dos toques, com detalhes importantes, demonstrando estar realizando excelente trabalho etnográfico, Estes dados permitiram que, na correspondência seguinte, Herskovits identificasse relações entre voduns da casa com o culto dos ancestrais da família real do Domé, fato ainda não identificado no Novo Mundo.

21. SF - Interessantes as observações sobre o transe discreto dos voduns que conversam entre si e com os presentes. 
ideias e, às vezes, ele tem me indicando pistas interessantes. Aqui termino. Lembranças a Mrs. Herskovits e Jean e aos bons amigos. Meus melhores votos de um Feliz Natal para todos.

Um grande abraço do Octávio.

Meu endereço para o futuro: A/C do Doutor Cesário Veras, Diretoria de Saúde e Assistência ${ }^{22}$.

São Luis (MA), $1^{\circ}$ de Janeiro de 1944

Carta $n^{\circ} 7$

Meu caro Dr. Herskovits,

Acabo de receber sua carta datada do dia 18 de dezembro. Sua carta anterior de 8 de dezembro não chegou até mim mas espero que não se demore muito pelo caminho. Quanto à carta a que fiz referência quando de último lhe escrevi, uma que, segundo meu pai, o senhor me enviará para Bebedouro, foi um engano deste; era uma comunicação da "Alumni Association" da Universidade.

Sua sugestão de que eu tome Caxias (ou a região de Caxias) para o estudo no interior veio ao encontro, interessantemente, dos meus planos. Digo a região de Caxias porque é perto desta cidade, em Codó, onde, ao que parece, se encontram costumes africanos em maior quantidade. Segundo fui informado, esta é a única região onde há tambores de minas que não são de exportação sanluizense [ludovicense], como é o caso em Viana e Rosário. Na zona de Guimarães e Cururupu, para o lado do Pará, não há tambores ao que fui informado. Desta forma, a não ser que eu saiba de algum lugar mais apropriado para as finalidades do meu trabalho, deverei embarcar para Codó nos últimos dias deste mês.

Ainda a respeito da viagem para o interior, devo pedir-lhe que me faça o favor de enviar uma outra prestação da subvenção da Rockefeller. 0 Banco do Brasil, aqui em São Luís, fará a transação.

$\mathrm{E}$, por falar em dinheiro, não vejo porque não hei de mencionar os aspectos financeiros da pesquisa. Fim de ano e festas foram uma ocasião em que "sangrei” bastante. Na Bahia, não lhe pediram "festas"? Pois aqui, só o Interventor, para ser bastante exagerado, não me pediu. Mas todos caíram sobre mim como se eu fosse a Rockefeller. Dei bastante e com prazer, mas, às vezes, a coisa quase chegou a ser exploração e eu odeio que me façam de "besta".

Enfim, tudo se arranjou a contento geral, meu e deles.

Quanto à obtenção de dados, pesa-me confessar que tenho andado ultimamente um pouco sem sorte, pois não tenho podido dedicar-me intensamente ao trabalho. De duas semanas a

22. RR - Em resposta, redigida em 11 de Janeiro, Herskovits exalta: "It was find to get your letter of December 10, and I am greatly pleased at the amount and kind of materials you are getting. The sort of Dahomean survivals you are finding do not, as far as I know, exist anywhere else in the New World, and as I said before, it is particularly fascinating that the cult of the Royal Ancestors has been so fully preserved. It looks like you are going to have a very nice thesis indeed. What is especially intriguing is the way in which minor details check with the African data, such as the fact that in each 'family' of deities, the youngest is the cleverest. Also is the way in which the affiliations, and the way in which the functions of the several pantheons are identical with their Dahomean counterparts. The one puzzling element is the absence of the Legba cult. Perhaps Hunuco is the answer, and I shall wait with particular interest for word of what you find concerning this spirit. As you know, each African god has so many 'praise-names' that this might be a case of the retention of one of these. Certainly, this name has a good Fon sound. Incidentally, the extreme institutionalization of possession is also very characteristic of Dahomey" (HERSKOVITS, BOX 27, Folder 34). 
estas partes, fui atacado por uma colite danada que me abateu bastante, perdi algum peso e andei bastante cansado. Ao que parece, estou agora me reestabelecendo ${ }^{23}$. Entretanto, colhi algum material. Em primeiro lugar, entretanto, antes de lhe comunicar qualquer coisa, deixeme dizer-lhe que a informação que lhe dei sobre [Huno'co] não é verdadeira. [Huno'co] não é senão [Guno'co]. Não é Jêje, como eu pensei, mas sim nagô e a própria Mãe Andreza declarou que não pertence à sua casa, mas à de Nagô. [Guno'co] ${ }^{24}$ é, como o senhor sabe, o nome tapa de Xangô (é melhor eu escrever estes nomes à brasileira). Sobre este obtive alguns dados interessantes; posso, felizmente, dizer-lhe que o "gelo nagô" está se quebrando. Xangô, que identificam como São Pedro, tem vários nomes, os quais tomou indo de uma cidade para outra. Em cada lugar por onde passava, arranjava uma mulher em um filho. Os filhos, deixavamos para Iemanjá ou Ori Manjá (Ori é o título da família de Xangô) e que ela os criasse. Esta perseguiu-o pelas sete cidades até que finalmente encontrando-o cantou: "Oh Badé, oh Badé, se tu me não levas contigo, eu vou".

A questão dos sincretismos afro-católicos não é abordada com muita vontade pelas iniciadas da Casa de Jêje. A mesma que me tinha feito uma declaração sobre identificações, coisa que descrevi numa carta anterior, procurou, um dia, ao que penso, despistar-me ou lançar um pouco de confusão na minha mente dizendo que os voduns (este termo e "encantado" são os dois mais usados, orixá sendo raramente empregado) nasceram nos dias de certo santos que eram assim seus advogados ou protetores. Será despistamento, o senhor acha ${ }^{25}$ Enfım, estou de atalaia para verificar bem isto. As da Casa de Nagô, embora não de todo desejosas, têm abordado a questão com mais liberdade. Xapassá e São Sebastião; Iemanjá é Nossa Senhora do Bom Parto; Abê ou Navê Uruari é Nossa Senhora da Conceição; Vunderegi é Santo Antônio; Ogum é São João; Akosse é São Lázaro; São José é Oto Orimateia ou Toia Ze'zinho; Servana (será nagô?) é Nossa Senhora dos Remédios. Dossú que (reconhecem como jêje) é São Jorge. Esta lista é idêntica a uma outra que me foi dada por uma mãe de um terreiro no subúrbio. Minha impressão é que os nomes africanos estão sendo esquecidos e substituídos pelos primeiros nomes dos santos na frente dos quais se coloca "Reis" ou "Dom". Assim, São Sebastião é Reis Sebastião, São João, Dom João, São José, Toia Ze'zinho (Tói, a propósito, é o tratamento dos voduns velhos na Casa de Jêje), São Luís é Dom Luís Rei de França ${ }^{26}$.

Quanto aos sincretismos Jêjes-nagô, os da Casa de Nagô, e, ao parece, os da Casa de Jêje também, crêem que as divindades são as mesmas e apenas têm nomes diferentes que se correspondem. Ainda a propósito do que me disse a informante Jêje sobre os voduns, e sua relação com os santos, bem pode ser que esta explicação não tenha sido para me despistar e seja verdadeira; realmente, não há muito a distância a separar esta explicação da crença ou explicação, para usar o termo, "sincrética".

Dados que tenho obtido sobre a constituição das casas de minas aqui permitem-me avançar, dependendo naturalmente de mais provas, que a "lei" de Jêje é mais tradicionalista e menos maleável que a "lei" de nagô. De fato, no princípio só havia as duas casas, tendo ambas sido fundadas aproximadamente na mesma época, alguns anos antes da libertação dos escravos ou

23. SF - Comenta problemas de saúde que enfrentou no trabalho de campo.

24. SF - Correção do nome do vodum Gunoco, que identifica como nome tapa de Xangô e comentários sobre aspecto da mitologia dos orixás.

25. SF - De fato até hoje o povo de mina diz isto no Maranhão.

26. SF - Costa Eduardo conseguiu também muitas informações sobre o sincretismo dos voduns com os santos e nomes de muitas entidades cultuadas na Casa de Nagô. 
por esta época. Ao passo que nenhuma vodunsi da casa de Jêje jamais se desligou da sua casa para fundar outro terreiro, várias nagôs, da Casa de Nagô, estabeleceram seus próprios terreiros. Ao mesmo tempo, as jêje só cantam em jêje enquanto as nagôs cantam para começar o tambor em nagô; depois o "tambor vira" e cantam em português, sendo chamadas as "linhas" de gentil e caboclo. 0 que seja esta linha de gentil ainda não está claro.

A distinção que, na Casa de Jêje, se faz entre os participantes e a que se refere à iniciação; há as que são feitas (hungaí) e as que não o são, sendo a maioria destas últimas. 0 período de iniciação é curto, quero dizer o período de reclusão na camarilha: 9 ou 15 dias. A iniciação é feita por grupos ${ }^{27}$. As participantes dos outros terreiros não são feitas; parece que só tiveram as cabeças banhadas. Apenas a mãe de terreiro da Casa de Nagô, ao que consta, foi feita individualmente. As velhas nagôs não foram tão solícitas como as jêje em transmitir seus conhecimentos do culto às suas descendentes, as crioulas. Na Casa de Nagô dizem que as velhas foram más; elas justificavam-se por não ensinar às descendentes dizendo que as crioulas eram "salientes", isto é, não saberiam usar os ensinamentos e aplicá-los devidamente, que de posse dele haveriam de querer mostrar-se. Estes, ao que me parece, são dados interessantes para o estudo do mecanismo de transmissão cultural ${ }^{28}$.

Os dados sobre Legba, a princípio escassos, estão agora aparecendo. Ainda não ouvi o nome Exú e quando eu o pronuncio não é reconhecido. As jêjes dizem que Legba é nagô e, ao que parece, não o cultuam. As nagôs reconhecem-no e identificam-no com o Cão, isto é, o Diabo. Este é um ser mau. Não vem atrapalhar, entretanto, porque atalham sua vinda no meio do caminho dando-lhe comida. Outras informantes, de outras casas, embora façam a mesma identifıcação, e embora queiram evitá-lo, dizem "ter ouvido dizer" que ele faz bem para certas pessoas. Ainda não sei bem o que pensar desta situação, mas me parece curioso que nas casas principais e mais conservadoras o nosso "trickster", ou seja, desconhecido ou julgado dum ponto de vista não africano ${ }^{29}$.

Há aqui outra modalidade de tambor, de que ainda não lhe falei. É o tambor de crioula. Vi um, o primeiro, ontem à noite. Não é de caráter religioso, mas puramente para diversão. 0 que eu vi realizou-se em plena rua num dos subúrbios. Também não há possessão. A orquestra é composta de três tambores. 0 maior é colocado entre as pernas do tocador, que se mantém inclinado sobre ele, e amarrado à sua cintura. Os outros dois, menores, são colocados no chão sobre um madeiro roliço e os tocadores sentam-se sobre eles. São de uma só boca e tocados com as mãos. As cantigas são em português e há improvisação. Dançam homens ou mulheres, um de cada vez, em frente aos tambores, a maior parte do tempo. Às vezes, dirigem-se aos espectadores e dão-lhes uma "punga" (empurrão com joelhos) ou "embigada" (empurrão com o estômago) ${ }^{30}$.

Informações de caráter histórico não consegui ainda. A busca na alfândega foi infrutífera, desgraçadamente. Há uma família aqui que tem documentos antigos e [...], então; eu encontrei alguma coisa. Como o chefe da família não está na cidade, nada foi possível até agora.

Quanto ao material sobre a vida de família, continuo obtendo o que posso. Pelos registros de nascimento do Registro Civil tenho obtido dados sobre uniões extra-legais em ilegitimidade.

27. SF - Apresenta informações importantes sobre a iniciação na Casa das Minas, comentando que há dois grupos de iniciadas, as vodunsi-gonjaí e as vodunsi-he.

28. SF - Afirmações que são feitas até hoje.

29. SF - Informações precisas e corretas sobre o desconhecimento de Legba ou Exu. 0 desconhecimento do trickster no tambor de mina até hoje intriga muitos pesquisadores.

30. SF - Distingue corretamente os dois tipos de tambor e descreve corretamente o tambor de crioula, afirmando entretanto que é puramente para diversão. 
Tenho pensado em fazer um estudo intensivo de umas 50 famílias, procurando saber coisas como as seguintes: a filiação do casal, isto é, se os pais eram casados ou não. 0 histórico de vida de cada um ou menos de como vieram a se casar ou juntar, o número de filhos, quantos criaram e quantos deram para criar, se criaram filhos dos outros, razões para uma outra coisa. Que outras coisas o senhor sugere? Acha que o plano pode ser levado adiante?

Há aqui uma maneira, acho que tipicamente africana, de chamar os filhos, quer carnais ou de criação, de mamãe, mamãezinha, papai, papaizinho. As jêjes, ao que parece, acreditam na reencarnação dos pais. 0 resto da população usa esta terminologia, mas, aparentemente, não a liga à esta crença.

Devo aqui terminar esta infındável carta. 0 senhor é capaz de ficar muito caceteado. Mas, antes, como me lembro e me parece importante, deixe-me dizer-lhe isto: 9 dos 30 e poucos terreiros $^{31}$ daqui foram assentados por curadores, sendo uma das causas, talvez a principal, a perseguição da polícia às suas atividades. Assim esses terreiros encobrem as suas curas ${ }^{32}$. Muito grato pelos votos de Feliz Ano Novo, os quais sinceramente retribuo à Mrs. Herskovits, Jean e ao senhor. Suas cartas são para mim um grande incentivo e sinto sempre um grande prazer em ouvir notícias suas e dos amigos e colegas.

Abraços ao Dick pelo sucesso, sem dúvida, da sua conferência. Receba um forte abraço do discípulo e amigo Octávio.

P.S. Recebi sua conferência pronunciada na Bahia e gostei muito ${ }^{33}$. De pleno acordo quanto à possessão. Meu endereço é:

Aos cuidados do Dr. Cesário Veras, Diretoria de Saúde e Assistência ${ }^{34}$.

31. SF - É importante a constatação de que na época funcionavam trinta e poucos terreiros em São Luís, feita pelo pesquisador dois meses após ter chegado à cidade.

32. SF - Observação válida ainda hoje.

33. RR - Trata-se de conferência pronunciada por Herskovits em 6 de maio de 1942, como aula inaugural da Faculdade de Filosofia da Bahia. Foi traduzida e publicada, em 1943, com o título de Pesquisas etnológicas na Bahia. Cf. HERSKOVITS (1943a).

34. RR - Em sua resposta, redigida em 27 de Janeiro de 1944, Herskovits encoraja o aluno: "I am glad to learn that the reticence of the Nago group is being broken down. You will find that when you return from the interior, and come back as an 'old timer' the unfilled parts of your account will begin to fill in, so I wouldn't be impatient if not too much comes to you at the present time. Keep after the Legba problem. You seem to be making some progress, and the point is too important not to resolve before the end of your stay. I would keep it particularly in mind when you go into the interior [...] Your project about studying intensively 50 families, again sounds good. I should say that it depends on the amount of time it makes to gather these data. If these people belong to African cult groups, it would be interesting to get the cult affiliations and the principal deities, if you can, of all the members of the family, to see whether or not there were any general principles that would come out regarding the influence of membership of such groups, or affiliation with them, on the selection of mates" (HERSKOVITS, BOX 27, Folder 34).

35. SF - Costa Eduardo constata a importância da identificação feita por Herskovits dos voduns cultuados na Casa das Minas com antepassados da família real do Daomé. Acredita que as vodunsis não tinham a menor ideia destas relações e, portanto, não identificavam na época relações entre os fundadores da Casa das Minas com membros da família real que teriam sido deportados para o Maranhão. 
São Luís (MA), 18 de Janeiro de 1944

Carta $n^{\circ} 8$

Caro Dr. Herskovits,

Acabo de receber sua carta de 11 de janeiro que, como o senhor pode ver pelas datas, bateu um "record" de velocidade. A de 8 de dezembro recebi-a há apenas alguns dias atrás.

Satisfaz-me naturalmente saber que o senhor ache que meu trabalho não vai mal, muito embora eu próprio pense que não passo de um principiante na arte de obter informações.

Seus esclarecimentos sobre os nomes das divindades jêjes aqui cultuadas caíram como uma bomba. Eu, realmente, estava sem uma explicação para aqueles nomes que eu nunca tinha ouvido antes. 0 senhor sugere que eu faça alguma pergunta a respeito deste culto dos antepassados reais? Minha impressão é que as pretas da Casa das Minas não têm a mínima ideia a este respeito; estes antepassados reais são voduns como os outros e suas funções e comportamentos são idênticos ${ }^{35}$.

Seu desejo de "estar na minha pele", como aqui dizemos vulgarmente, não me causou espanto nenhum. Na verdade, eu de há muito havia antecipado que o senhor e Mrs. Herskovits estariam de uma certa forma invejando, e isto eu havia dito já várias vezes à Mãe Andreza e suas vodunsi. Tenho falado a seu respeito várias vezes a elas e assim ou senhor já é conhecido. É realmente uma pena que o senhor não tenha a oportunidade de ver as jêjes dançar. E os tambores, estes são magníficos. Se eu sair daqui sem gravar alguma coisa, isto de fato me desapontará.

As informações que obtive sobre Legba, transmiti-as na carta anterior e não tenho muito mais para dizer. Entretanto, continuarei a fazer mais sondagens a este respeito.

Não estou bem certo se já lhe falei com detalhe dos costumes mortuários. Como o senhor disse muito bem, os pretos são muito sensíveis a este respeito. 0 tambor de choro é chamado pelos jêje zemli quando é de corpo presente e sihum quando é realizado seis meses ou um ano após a morte da vodunsi ou tocador, porque não pode ter lugar por ocasião da morte da pessoa. 0 corpo é colocado numa sala; as vodunsi, na varanda, vestidas de branco, sentam-se em volta de uma bacia contendo água e vinho e aí cantam as cantigas fúnebres. Quem entra na varanda, coloca níqueis na bacia para as despesas da missa. Até o dia da missa, como na Bahia, rezam para a alma da defunta. Finto isto, não há mais nenhuma obrigação para com o espírito da morta. A vodunsi defunta veste as roupas do culto e as outras não são atiradas fora, como fazem os outros terreiros. Ficam para pessoa em que o vodum baixar. A “carrega” baiana é aqui chamada carga pelos cultos nagôs. Nestes, não há bacia e as participantes sentam-se ao redor do caixão da defunta. Na Casa de Jêje, se morre a mãe de terreiro ou uma hungaí, o hum também é tocado além dos outros tambores menores; para uma vodunsi que não é feita, não se toca o hum. Quanto aos músicos, só a gantó e os que tocam o hum têm direito a que este seja tocado ${ }^{36}$.

Depois da morte a alma vai para onde Deus determinar. Isto é uma coisa interessante: não há indícios de que haja aqui o culto dos antepassados. Por ocasião de casamento, não se pede a licença destes.

A preocupação de ter um enterro decente é grande. Ser enterrado pela polícia num "caixão pelado" é um pensamento que tortura os pretos $^{37}$. Quanto à vida económica e suas interrelações

36. SF - As informações sobre o tambor de choro são idênticas às que continuaram sendo observadas na Casa.

37. SF - Observações corretas sobre costumes mortuários. 
com a religião posso dizer-lhe que, como se era de esperar, as incertezas financeiras são diminuídas pela esperança de ajuda do sobrenatural. Fazem-se promessas aos santos, procurase a mãe de terreiro ou o curador. Uma sobrevivência mágica interessante diz respeito às vendedoras ambulantes de frutas e doces. Como na Bahia, se não vendem como desejam, batem com um ramo de pinhão roxo sobre o tabuleiro e dizem: Procura freguês ou procura teu dono. 0 elemento cooperativo está presente quando da cobertura de uma casa. Aqui, as casas dos pobres são cobertas com palmas. 0 proprietário convida 4 ou 5 amigos para ajudá-lo e lhes oferece bebida e às vezes almoço.

Finalmente, estou encontrando alguns dados sobre a procedência dos escravos. Examinando inventários amarelecidos do século passado deparei com dados que nos interessam. Um inventário de 1800 indica os seguintes escravos: angola -18; crioulo - 27; cacheo - 16; mina 2. (0 senhor sabe alguma coisa a respeito desta palavra cacheo? Não sei se se refere a Caxias, mas duvido). Outro: Mandinga -14; Bijajó - 13; Cacheo - 4; Crioulo - 14; Balanta - 4; Angola -

Num inventário de 1829, encontram-se: crioulos - 10; Moçambique - 1. Noutro: crioulos - 6; Mina - 1; Angola - 7; Mandinga - 1; Cabinda - 1. Noutro: Mandinga - 7; Crioula - 12; Angola - 7; Benguela - 5; Caçange - 2; Congo - 1; Mina - 1; Calabá - 1; Moçambique - 1.

Num inventário de 1837 vêm-se de Nação Nagô - 4; de Nação Cabinda - 3; Caçange - 1; Angola - 2; Congo - 2; de Nação Mina - 1; crioulos - 7.

Também examinei inventários de 1847 e a distribuição é mais ou menos idêntica. Espero ver mais inventários porque estes dados, embora um exame perfunctório revele coisas interessantes, não são, ao que me parece, conclusivos. Desde 1800, como se vê, estavam entrando escravos de Angola. De outro lado, eu noto a quase ausência de nagôs e a ausência absoluta de jêjes. Naturalmente, o senhor terá alguma coisa para me dizer sobre estes dados proximamente. Parece-me que vieram muitos Angolas para cá e eu suspeito que o tambor de crioula (o coco baiano, penso) é de origem Angola. De outra parte, é interessante que não haja sobrevivências religiosas angolas. Cabinda, houve, pois já lhe disse, havia aqui um tambor cabinda.

$\mathrm{Eu}$, provavelmente, devo estar em erro separando cabinda e angola. Não são ambos da mesma região? Mas, conservando a terminologia, devo dizer-lhe que em algumas cantigas cabinda, que Mãe Andreza cantou para mim, aparecem os nomes Tufamama (Deus), Zembi, Paka e Kamundá38.

Quanto à viagem para o interior, decidi-me mesmo pela zona do Codó e lá procurarei uma povoação habitada só ou na sua maioria por pretos. Se for conveniente, voltarei a São Luís no dia 20 para ver o carnaval. Enquanto fora, Dr. Cesário Veras se encarregará da minha correspondência.

Dr. Teixeira agradece a remessa nas suas publicações. É uma esplêndida pessoa e de fato tem-me sido útil. Ele é ortopedista e tem estado bastante interessado em antropologia. Embora quarentão, eu penso que seria uma ótima pessoa para estudar com Krogman em Chicago ${ }^{39}$.

Enquanto estava escrevendo esta, recebi um pacote contendo minha correspondência que havia aí e que o senhor mandou para Bebedouro. Junto uma carta sua de 10 de setembro. Escreverei a meu mano para lhe enviar o livro de Gilberto, "Problemas Brasileiros de Antropologia", de que lhe falei e que o senhor menciona nesta carta. Não creio que lhe agradará. E, para usar uma expressão sua, "an horrible example of $[. . .]^{40}$ it should not be done". Quando à minha tese, embora traduzida, não penso publicá-la já. Desejo fazer antes um índice à americana.

38. SF - Constata-se a reocupação do pesquisador em encontrar nos documentos informações sobre origens dos escravos e em identificar nomes de possiveis entidades cambindas.

39. SF - Interessante a preocupação de identificar futuros pesquisadores nativos.

40. RR - Não foi possivel identificar a palavra empregada por Costa Eduardo. 
A propósito de Dona Heloísa, tenho más notícias. Pelos jornais, eu soube que um incêndio destruiu parte das coleções de antropologia, história natural, etc., do Museu.

As notícias sobre todos daí me alegram bastante. E quais são as novidades sobre os Bauers? Por favor, lembre-me a todos.

À Mrs. Herskovits e Jean, muitas saudades.

Embora esta carta esteja indo muito longe, há entretanto um assunto de que ainda não lhe falei em nenhuma das minhas cartas anteriores e para o qual, agora, peço a sua atenção. A natureza dele é bastante pessoal e para mim de grande importância. Tudo começou quando voltei para a minha casa em Bebedouro. Durante minha estada lá fiquei noivo, embora isto ainda não seja ofıcial, de uma moça, Maria Eugênia. Eu bem sabia que não podia me envolver assim por causa dos meus estudos, minha vinda ao Maranhão e subsequente volta aos Estados Unidos. Mas, absolutamente não pude evitar o que aconteceu e, agora, estou eu amarrado a dois compromissos, sem saber como hei de satisfazer os dois sem dessatisfazer a ninguém e a mim mesmo. Confesso-lhe que esta situação me tem feito pensar muito e só não lhe escrevi antes a este respeito porque desejava ponderar bastante.

Bem sei que não lhe devo importunar com pedidos e, creia-me, aborrece-me bastante fazêlo, mas sou forçado por causa das circunstâncias a lhe perguntar se a Fundação Rockefeller aumentaria meu "grant".

Minha noiva é bem jovem, boa menina, e sem ser uma intelectual não deixa de ser aproveitável. Talvez ela venha a ser uma estudante de antropologia como eu. Pesa-me aborrecêlo assim e espero que o senhor me desculpe.

Com um abraço, sou sempre seu amigo grato e discípulo 0ctávio ${ }^{41}$.

41. RR - Em carta de 3 de Fevereiro de 1944, Herskovits sugere: I realize how anxious you are to get married, and sympathize with your feeling. Would it not be possible for you, on your return to Bebedouro, to marry, have a few weeks with Maria Eugênia, and them come on for your work here. I may say that this is exactly what happened to us. We were married in Paris, were together only intermittently during the following two months because of the demands of my fellowship program, and then I had to come home more than a half a year before Mrs. Herskovits could. I realize, therefore, that what I am suggesting is not easy, but I am convinced that in the long run neither of you will regret the step. E acrescenta: Keep boring into the problem of funeral cult. You are getting farther than you realize. For instance, the Jêje zemli is the word used in Dahomey for the funeral drum-zeli [...] The whole pattern of the funeral ritual follows very closely the Dahomian, and I expect will even more in detail [...] The documents that you have found are of the first importance, since, as you know, the law under which materials pertaining to slavery were burned, and has made data of this kind extremely rare. I haven't the faintest idea what cacheo might mean, but I will start looking art some of the African maps, particularly some of the early ones to see if I can find a lead. You are quite right about Cabinda. I am enclosing a bit of a map of West Africa that I copied off for you, showing you were Cabinda is. You will see that it was a very important port for the slave trade at the mouth of the Congo, and that the Negroes brought from there should, as you have assumed, be classified as Congo. I think you would be doing Brazilian scholarship a service if you could induce the owners of these documents, provided they are in private hands, to deposit them in some archives, perhaps with the Museu Nacional (HERSKOVITS, BOX 27, Folder 34). 
São Luís (MA), 9 de Fevereiro de 1944

Caro Dr. Herskovits,

Recebi sua carta de 27 de Janeiro na sexta-feira, dia 4. Esperei alguns dias para lhe escrever à espera que o dinheiro que a tesouraria da Universidade me enviou chegasse às minhas mãos. Mas, até agora, o Banco do Brasil não recebeu nenhuma comunicação a respeito deste dinheiro. Por via das dúvidas, peço-lhe que verifıque se a remessa foi feita em ordem. De qualquer forma, tenha eu recebido o dinheiro ou não, até o dia 14, o mais tardar partirei para o interior. $\mathrm{Na}$ verdade, já estou bem atrasado pois já pretendia ter partido; esta demora me aborrece bastante. Segundo as informações que tenho obtido, o melhor lugar para eu ir parece ser a povoação de Santo Antônio, distante da cidade de Codó 60 quilômetros. É habitada exclusivamente por pretos e está, ao que parece, relativamente isolada. De Codó até lá faz-se uma viagem nessa época de chuvas a cavalo.

Lembro-me de que falamos sobre a possibilidade de eu vir a estudar uma comunidade habitada por descendentes de negros fugidos. Não creio que Santo Antônio seja uma destas. Há, entretanto, duas povoações no lado paraense do Rio Gurupi, chamadas Camiranga e Tamauari, vizinha uma da outra, que são remanescentes de antigos quilombos. Duas pessoas me informaram sobre elas: um advogado que as visitou em 1932 e o Diretor da Biblioteca do Estado que trabalhou nessa região como agente do fisco; a zona é aurífera. Embora o advogado me tenha dito que os habitantes levam uma vida africana, pouca coisa soube me explicar; o outro senhor, por sua vez, disse-me que há lá uma escola, que Camiranga é habitada por brancos também e que esta vila não difere das outras do interior do Maranhão. Assistiu um Tambor de Mina, em que dançavam homens e mulheres; os tambores eram de uma boca só e as cantigas, tanto quanto se lembra, eram um misto de africano em português. Que acha o senhor disto? Há vantagem de eu ir mais tarde a essas povoações? A dificuldade maior é a de transporte; ao que me dizem, a viagem daqui até lá dura de 5 a 7 dias.

Ontem, recebi seu artigo "Drums and drummers in Afro-Brazilian Cult Life"42. Muito grato pela sua bondade mandar tirar esta cópia para mim. Está lindamente escrito eu gostei imensamente de tê-lo lido. Sugere-me uma porção de pontos aos quais eu não tinha prestado muita atenção, mas, agora, estou bem atentado. As observações sobre as atitudes e a personalidade dos tocadores estão muito bem traçadas; o mesmo tenho observado por aqui. 0 costume de batizar e dar comida aos tambores também existe em São Luís. Esta obrigação para com os tambores não é, entretanto, feita tão regularmente como na Bahia. Na casa de Jêje, há mais de 10 anos que não fazem. Na Casa de Nagô, no dia 23 de janeiro, uma filha de santo ofereceu um prato de cururu ao dono da casa, Xangô. Nesta ocasião o tambor também come. Esta obrigação, que tem lugar durante o ritual público, é chamada amalá. Para duas outras casas, registrei o costume de dar comida aos tambores e segundo os informantes isto é feito na véspera do dia em que se comemora o aniversário do primeiro tambor realizado na casa. Confırmo a importância dos tambores no culto, mas devo notar que me foi dito várias vezes que o ferro é que marca o ritmo. $\mathrm{Na}$ Casa de Jêje, além das suas funções como músicos, os tocadores também se encarregam da matança, principalmente o Aumtó-chefe ${ }^{43}$ (o termo alabe não é conhecido).

42. RR - Cf. HERSKOVITS (1966 [1944]).

43. SF - Atualmente o tocador chefe é conhecido como huntó, termo que pode ser traduzido como tocador de tambor. 
Nenhuma cerimônia é mais demonstrativa do importantíssimo papel dos tocadores e dos tambores no culto do que o tambor de pagamento das casas Jêje e de Nagô; na primeira é muito mais africano na sua forma ritualística do que na última. A ideia deste tambor é a seguinte: os tocadores de tambor e os outros merecem uma recompensa por terem tocado para os voduns dançar; assim, os voduns os tocadores. Na Casa de Jêje, cada tocador recebeu 5.000, uma camisa, um lenço, uma garrafa de vinho. Na Casa de Nagô, alguns cruzeiros e uma garrafa de vinho. Isto não tem lugar todo ano, mas a ideia é que se faça anualmente. 0 tambor de pagamento $^{44}$ na Casa Jêje foi realizado no dia 6 de janeiro, dia de Reis, no quintal e não na varanda da casa como são os outros. À frente, vinham os tukhueno, os guias dos voduns, tendo em suas mãos os presentes. Seguiam-se os outros. À medida que cantavam uma linda cantiga, apropriada para ocasião, faziam a entrega dos presentes. Depois disso, o ritual prosseguiu como de costume. Foi uma das festas mais lindas que já $\mathrm{vi}^{45}$ e tive a sorte de tirar fotografias, isto é, um fotógrafo profissional tirou-as para mim. Infelizmente, por falta de papel, ainda não recebi as cópias senão mandar-lhe-ia algumas. 0 tambor de pagamento da casa de Nagô não foi tão "hot". Teve lugar na varanda da casa, à noite, e a cantiga de entrega dos presentes, bem curta, só tinha de africano os nomes Sobô e Badeé o ritmo.

Vem aqui a propósito contar-lhe um desapontamento meu que também reflete a qualidade sagrada dos tambores e do culto das Jêjes. Com algum esforço, consegui comprar dez discos para fazer gravações, arranjar uma máquina gravadora e o técnico com o Diretor do Departamento de Imprensa e Propaganda. Só faltava autorização da mãe do terreiro. Mas, ela disse que não dependia dela: “dependia deles”. Isto foi há poucos dias, no dia 4. À noite, houve um tambor. Falei com Poliboji, que é o senhor da mãe do terreiro, humbone ${ }^{46}$ e não Ponhânsâma, como lhe disse anteriormente, este sendo um dos seus nomes africanos (as hungai têm dois). A resposta de Poliboji, dada amavelmente, mas num tom firme, foi que o velho, Dadarrô, não queria que se gravassem os ritmos dos tambores. Foi, falo com franqueza, uma recusa que eu não esperava ${ }^{47}$ porque agora eu sou filho da casa, sou bem do coração das pretas. Não sei se recusaram porque talvez pensem que eu quero as músicas para propaganda, mas não creio, embora, ontem, o rumto-chefe de lá me tenha dito alguma coisa a esse respeito. Expliquei-lhe que queria fazer as gravações porque desejava ter uma lembrança delas comigo, de tanto que eu gosto da música, e porque queria que o meu professor também as ouvisse. Enfım, tenho esperança de que na minha volta eu consiga alguma coisa. Mas, creio que isto ilustra bem o que eu disse acima.

Novamente, volto a dizer-lhe que a música Jêje é a coisa mais formidável, mais emocionante, mais estupenda que se pode imaginar. Eu não entendo de música, mas posso jurar de pés juntos que estou para ouvir coisa semelhante. De um módulo geralíssimo, quero dizer, muito geral, distinguem-se quatro ritmos fundamentais, segundo se toca para Keviossô, Dambirá, Davisse ou Tokhueno. Para Davisse, a princípio o toque lento (compasso) mas no auge se torna rápido (corrido). Para Dambirá, o padrão é mais ou menos o mesmo só que é mais rápido no começo. 0 ritmo para Keviossô é fantástico; rápido (corrido) do começo ao fim. Para Tokhueno, a música é também é rápida, mas é mais leve do que para Keviossô. Os Tokhueno são voduns moços;

44. SF - Na Casa das Minas o tambor de pagamento inclui oferta de alimentos a todos os voduns cultuados, que acarreta sacrifícios de animais e a respectiva distribuição de alimentos. No tambor de pagamento realizado em 1985 foram oferecidas aos voduns 52 aves (Ferretti, S. 1995: 191).

45. SF - Descrição exata do tambor de pagamento dos jeje.

46. SF - Humbone ou humbono é o nome dado à mãe de santo ou mãe do terreiro na Casa das Minas. 47. SF - Constatação pelo pesquisador do antigo costume da Casa das Minas Jeje de não permitir gravações de suas músicas. 
pertencem à familia de Davisse. Nada se faz sem eles. São os mensageiros dos voduns velhos. Quando um destes quer mandar um recado ${ }^{48}$ para alguma vodunsi, manda um tokhueno. Quando há tambor, eles vêm limpar, abrir o caminho para os outros voduns. Se se atrasam, isto é, se demoram a baixar, o que acontece raramente, cantam a seus pais (Davisse), pedindo desculpas.

Legba, ao que parece, está mesmo ausente do culto Jêje. Perguntas, diretas ou indiretas, não me levam a lugar nenhum. 0 nome de Exú pouco é reconhecido pelas nagôs ou pela gente de outros terceiros. Ontem, um Informante falou-me de Legba Exú de Codó, a respeito do qual entretanto não sabe muito (verei o que há pelo Codó a esse respeito). Quanto ao encantado que pode transtornar o tambor se não é satisfeito, este, disse-me, é Suraupira (o Cão, isto é, o Diabo) ao qual se oferece uma galinha uma vez por ano, em geral na Aleluia, num lugar afastado.

Ao contrário do que o senhor observou na Bahia (Book B, p. 122, 1 linha), os tambores aqui seguem o calendário católico. Pelo menos os dias de Santa Bárbara, Santa Luzia, Natal, Ano Bom, Reis, São Sebastião, N.S. do Bom Parto, foram dias de tambor. Um fato interessante são as ladainhas realizadas nas casas de mina antes do tambor começar nos dias de festas de obrigação. Contrata-se uma orquestra de três figuras e canta-se a ladainha em português e latim na sala dos santos católicos. Na casa de Jêje, finda esta ladainha de igreja há a ladainha dos voduns, cantada em Jêje pelos voduns em que louvam o vodum ou a família de voduns do dia; no dia de Santa Bárbara, foi a família de Keviossô; no São Sebastião, foi a Akosse Sapatá (Danbirá). Para as Jêjes, além de São Sebastião também São Lázaro (sapatá) é o santo dos pretos.

Uma espécie de espíritos de que ainda não lhe falei são as tobossa, as meninas. Só as hungai é que as têm. Vêm três vezes por ano: começo, carnaval e junho. Ao contrário dos voduns, baixam apenas em certas hungai; mortas estas, não vêm mais. Quando possuídas pelas meninas, as iniciadas, que se vestem diferentemente, enroladas num pano que as cobre dos seios para baixo, tendo os ombros nus, exibem uns comportamentos tipicamente infantil: brincam com bonecas e coisas de cozinha de brinquedo, enfiam contas, falam como crianças, são cheias de gostos. Antigamente, segundo dizem as Jêjes, havia umas vinte meninas. Agora só vieram três ${ }^{49}$. Mais dados sobre a procedência dos escravos confirmam o que lhe disse na minha carta anterior. Espero ansiosamente sua publicação sobre a religião daomeiana e as outras que o senhor enviou. Enquanto no interior, farei o possivel para lhe remeter notícias. Doutor Veras se encarregará de enviar minhas correspondências para o interior.

Poderia o senhor fazer-me o favor de pagar a minha anuidade da Society of Sigma Xi? Não estou certo se é um ou se são dois dólares. Lembranças a Mrs. Herskovits e Jean.

Abraços do Octávio ${ }^{50}$.

48. SF - Apresenta observações exatas sobre funções dos tokhuenos ou toquenos e os ritmos dos toques, lento ou corrido conforme as família (Quevioço, Davisse, Dambirá), ou as categorias de voduns (toquenos - os mais jovens).

49. SF - Informações sobre as tobossis e os toquenos são idênticas as que sempre ouvimos na Casa Jeje. 50. RR - Em 29 de Fevereiro, Herskovits responde: "I do not think that it will be necessary for you to go to Camiranga e Tamauari, unless questionning in the interior seems to indicate that these are of unusual importance, or that the materials at Codó do not come up to your expectations [...] What you say about the Tohweno Cult is again most interesting. It makes me wonder whether or not they do not tie up the concept of the "little people" whom we found so important in West Africa and Guiana with the erê of Bahia-meninas. What about the erê, by the way, in the North?” (HERSKOVITS, BOX 27, Folder 34). 
Codó (MA), 14 de Fevereiro de 1944

Carta $n^{\circ} 10$

Meu Caro Dr. Herskovits,

Sua carta de 3 chegou-me às mãos há alguns dias, quando ainda em São Luís, mas não me foi possível respondê-la de lá devido às muitas atrapalhações que surgiram: preparativos de viagem, money trouble (o dinheiro da Rockefeller ainda não veio) e uma viagem perdida, aliás, que fiz uma vila próxima para assistir a inauguração de um terreiro; este ritual foi transferido. Muito grato pelas suas felicitações, pelas suas bondosas palavras. Folgo imenso em que o senhor também compreenda o predicado em que estou e agradeço-lhe muito pelos seus bons conselhos. Seria, entretanto, muito difícil para Maria Eugênia e para mim, não distante minha qualidade de estudante em antropologia, adotar a solução que o senhor sugere. Isto não seria fácil nem para ela e nem para mim, como o senhor diz e, em segundo lugar, não creio que nossas famílias compreenderiam, brasileiríssimas que são. Mas, não pense que irei desapontá-lo e criar com isso dificuldades para outros pratos patrícios meus, que venham a ter as mesmas maravilhosas oportunidades de pesquisa e de estudo que me têm sido concedidas por iniciativa sua. Aliás, sempre tive estas duas coisas bem em mente e não disse uma palavra, estou certo, nem ao Senhor e nem ao Jimmy, de que eu interromperia o programa que foi traçado para mim. Entretanto, isto não envolve necessariamente a suposição de que eu tenha desistido da ideia de me casar antes de voltar para os Estados Unidos. Continuo a ter o mesmo propósito e só não o realizarei se não puder. Mas, se eu não conseguir o que almejo, voltarei mesmo assim, este ano ainda que só e solteiro. Sei que vai ser duríssimo, mas esta é a solução. Até parece que estou me tornando um herói de uma tragédia corneliana!

Cheguei aqui apenas há algumas horas depois de uma viagem monótona e fatigante de 12 horas. Mesmo assim, embora cansado, prosseguirei viagem amanhã pela manhã pois graças a uma coincidência feliz já arranjei companhia e animal.

Na carta anterior falei-lhe de uma cerimônia chamada amalá. Estava meio enganado. 0 amalá é carurú com bolas de acarajé e dança-se o amalá fazendo-se a oferta dele a Xangô ou outro vodum. Por isso, parece-me que não há mal em se denominar o amalá também de cerimônia ou ritual, mas, na verdade, isto não é muito importante.

Uma correção importante, agora. De fato, os nagôs não conhecem o nome Exú mas conhecem Lebara. De uma vodunsi importante na casa ${ }^{51}$, obtive o seguinte (transcrevo minhas notas): Não entra na casa de nagô porque cortam a sua vinda. Fica de longe por causa do trabalho que fazem antes. Não apenas nagô, mas Jêje também tem (entretanto, Mãe Andreza continua a dizer que não cultuam Lebara). É mau, não queremos negócio com ele. Faz-se sacrifício para ele sempre que se derrama sangue em sacrifícios para os outros. Antes de se fazer o serviço para os outros faz-se o serviço dele. Mata-se para ele um frango de cor, rajado; recolhe-se o sangue num prato. Faz-se o frango assado. Tudo para ele é separado: panela, colher, fogão. Quem trabalha para ele (quem prepara a comida dele) nem dá a mão para nós. Coloca-se tudo que se oferta para ele dentro de um cofo, tudo bem arranjadinho. Leva-se isto ao mar. As comidas para os outros são oferecidas no vardencó (peji) mas a comida para Lebara é conduzida à noite por uma dançante experimentada, um tocador e um barqueiro, para o mar. Nenhum deles diz palavra; comunicam-se por meio de gestos. Estão todos aterrorizados. Determina-se por admiração quem

51. SF - Observações importantes sobre a ausência do culto a Lebara na Casa das Minas e da prática de oferendas para sua evitação, com o uso do jogo de dados (3 búzios) na Casa de Nagô. 
há de conduzir a comida de Lebara. A mãe do terreiro jogos os dados (búzios - em número de 3); esta, incidentalmente, é a primeira referência a este respeito. Caso não se satisfizesse Lebara, que é o diabo, segundo Mogênia e Dudú, ele viria transtornar; as comidas não sairiam boas, ou as vodunsi brigariam entre si, algum barulho teria lugar durante o tambor. Quando mencionei encruzilhada, Dudú disse que pensa que é com motivos de fazer mal aos outros que se coloca a comida de Exú nas encruzilhadas; mas na Casa de Nagô não cuidam disto e a informante não sabe, disse, se fazem isto ou não nas outras casas. Sem comentários exceto o seguinte: este assunto parece ser muito mais perigoso do que em qualquer outra parte ${ }^{52}$.

Na casa de Jêje, nas festas grandes, de obrigação, há o zãdró e o nahunũ. 0 zadró é o toque na véspera do dia da festa de obrigação; então, os voduns vêm no peji, isto é, as vodunsi vão recebê-los lá em vez de recebê-los na varanda. Ocorre à noite. As vodunsi sentam-se enquanto os tocadores ficam [...]. Tocam batendo palmas e cantam chamando os voduns; as cantigas são diferentes das de dias de tambor comum. 0 nahunũ é o dia da matança, em que se oferecem o sacrifício.

Pelo Carnaval, as duas casas grandes, Jêje e Nagô, têm uma festa a que chamam ahuambã na primeira; aoambã na segunda. Nas outras casas é bancada. Consiste na distribuição de frutas, doces, bebidas etc. Não acha o senhor que tem alguma coisa a ver com o ritual dos primeiros frutos? Antes de repartidas, essas coisas são ofertadas aos voduns e conduzidas para o peji; são eles que, na quarta-feira de cinzas, fazem a distribuição ${ }^{53}$. Estas são as verificações mais recentes que fiz. Acho que são coisas que hão de interessar. Lembranças a Mrs. Herskovits, Jean e aos colegas e amigos.

Muitos abraços do Octávio ${ }^{54}$.

São Antônio dos Pretos (MA), 22 de Fevereiro de 1944

Carta no 11

Meu Caro Dr. Herskovits,

Espero que o senhor tenha recebido a carta que lhe enviei de Codó de 14 deste. No dia seguinte, fız a maior parte do trajeto desta cidade a Santo Antônio dos Pretos. Andei 52 quilômetros no lombo de uma burra. E na quarta-feira pela manhã depois de 8 quilômetros chegava ao meu destino. Creio não lhe precisar dizer o que foi esta viagem para mim, pobre citadino. Fato é que fiquei com corpo bastante dolorido e me cansei bastante. Por causa desta experiência, sou da opinião que inaugurem um curso de equitação anexo ao Departamento de Antropologia.

52. SF - Observações sobre Exu na Casa de Nagô continuam atuais.

53. SF - Interessantes as observações exatas do pesquisador sobre etapas que antecedem as festas grandes e o arrambã na Casa das Minas.

54. RR - Em 11 de março, Herskovits escreve: "It will be very interesting to learn from your future letters what you find in the interior. I feel a little more reassured about the results of your research concerning Legba during the last days of your stay in São Luis, and I predicted that when you come back from your stay in the interior as an 'old timer', you will clean this matter up in no time at all. The details of the way in which you describe how the 'food' for Lebera is taken at night to the sea sounds very much like the sort of thing that is done with the carrega for the dead in Bahia. I would suggest that you work further on this lead in Codó and when you return to São Luís, either if there might not have been some confusion here, or just what the meaning of this is. I am not surprised that they identify Legba with the devil, but this extreme fear of him, without the other side of the picture - a kind of affection - is curious" (HERSKOVITS, B0X 27, Folder 34). 
No povoado, hospedei-me na casa do negociante e mais rico lavrador, homem branco, primus inter pares. Ele e sua senhora têm sido gentilíssimos para comigo. Durmo na melhor sala da casa que é de pau a pique e coberta de palha como todas aqui. As refeições são boas e fartas embora não haja variedade, servem arroz, feijão, carne de porco ou galinha. Ovos. Às vezes, abóbora ou pepino. Esta é a época de melancias e já estou começando a me cansar de comê-las; às vezes, para variar, há melão. A higiene pessoal é que é uma dificuldade. Não há instalações sanitárias, como era de se esperar, e água, só a barrenta, ou sendo menos pessimista, bastante escura do Rio Codó que passa à porta. É um problema tomar-se um banho. Enfim, estes são os ossos do ofício, e já estou acostumado com tudo. Tenho tido o cuidado de só beber água servida e tomar quinino todas as noites; devido a isto não tenho o sono plenamente satisfeito mas sinto-me disposto durante o dia.

As habitações são em número de 50 com uma população de cerca de 150 pessoas. Vivem da agricultura, plantando principalmente arroz e milho e ainda algodão e mandioca. A terra, que foi comprada há muitos anos atrás pelos ascendentes de várias das famílias daqui, é possuída em comum por todos. Mas, devido ao fato que só dois pretos, já falecidos, assinaram a escritura de compra sem deixar herdeiros legítimos, a terra está sendo agora disputada por um terceiro. Cada casal ou cada indivíduo per se têm a sua própria roça. Esta eles cultivam auxiliando-se mutuamente. Como o senhor disse e eu próprio suspeitava, a tradição africana de cooperação nas atividades econômicas está aqui bem viva. Chamam a isto trocar dias. Um indivíduo trabalha para o outro e está ganhando um dia ou pagando um dia, conforme o caso. Em geral, quando um lavrador "põe outros no trabalho", como se diz, contrata 3, 4 ou 5. Depois, vai pagar o dia que os outros lhe deram a cada um deles; este, por sua vez, tem igual número trabalhando para ele. Quanto à divisão do trabalho por sexo, esta não é muito grande. As mulheres, pelo menos muitas delas, trabalham tanto como os homens e como estes capinam a roça, depois de plantada, semeiam e colhem. Apenas não limpam o terreno para plantar. Mulheres e homens trocam dias entre si, mas um informante disse-me que não troca seu dia pelo de qualquer mulher. Mas nem todos os trabalhadores trocam dias; alguns - uma grande minoria - preferem trabalhar apenas nas suas próprias roças dizendo que isto lhes convêm mais.

Há poucos casais legalmente constituídos. Os poucos que se casam, principalmente pela igreja, em geral dissolvem a união depois de algum tempo juntos. Vivem geralmente amasiados e algumas uniões persistem. Há alguns casos em que um homem tem duas mulheres.

São católicos, mas possuem também sua "casa grande" em que cultuam seus "budú" (provavelmente uma corruptela de vodum). Deles o principal é Kakamadô; tem filhos dos quais Atinvorô e Trovão, chamado Trovãozinho, são conhecidos. Outros "encantados" de que até agora conseguiu os nomes são Maria Barbara, Kolimeiro, Legua Boji. Lebara não vem aqui mas um dos principais do culto disse-me que ele "trabalha" no rapaz há duas léguas de Codó; e era só o que sabia. Sobre Légua Boji, um outro informante, residente há apenas 4 meses aqui, vindo de uma distância de umas 15 léguas, da cidade de Pedreiras, fez interessantes observações: tem dois corações, um para o bem e outro para o mal. Faz o bem, com o primeiro coração; àqueles que querem conversar amigavelmente com ele, com o outro coração, faz o mau àqueles que o ofendem. Não conhecem Xangô nem Badé. Quanto aos nomes acima, Kakamadô e Atinvorô, serão eles africanos?

Usam apenas um tambor comprido, de uma sua boca, oco, tocado com as mãos e não conhecem o agogô; mas usam berimbau ou marimbas e cabaças. Cantam em português e não sabem cantigas africanas. Homens e mulheres dançam. Cada vez que o encantado baixa numa festa, ele é conduzido para o quarto das pedras, urna, e aí se lhe banham a cabeça, as mãos e os pés com vevéu, uma mistura de água com folhas. 
Presentemente, não têm tido festas porque não têm dinheiro para comprar couro para o tambor. Naturalmente estou dando um jeito nisto e talvez para o sábado depois do próximo teremos um tambor de mina, mais conhecido aqui pelo nome pajé; os outros termos pelos quais é chamado são terecô, nagô, budú. Depois de amanhã, numa povoação distante daqui 2 léguas, se realizará um pajé "na visita” de um homem que faleceu há um mês atrás. Não tocam tambor no dia do falecimento de um membro do culto mas fazem-no 15 ou 30 dias depois. Dizem que a alma do homem vem apreciar o tambor e por isto se diz que se toca "na visita" do morto. Ao que me dizem, é uma festa como qualquer outra. Isto eu espero ver por mim mesmo.

Um informante deu-me dados interessantes sobre personalidade e conduta. Cada pessoa tem uma alma e um anjo da guarda que o protege. Este é um espírito santo nascido com o indivíduo. Não é responsável pelo bem ou mal que se faz em vida; quem paga pelos pecados é a alma. 0 anjo da guarda pode ser fraco ou forte, dependendo do indivíduo rezar pouco ou muito para ele. Quando o anjo da guarda é forte a pessoa sente atrás de si as suas passadas acompanhando-o. Durante o sono a alma passeia e é o anjo da guarda que fica respirando em lugar do espírito. Se alguma coisa está para acontecer ao corpo, o anjo da guarda chama o espírito de volta e o indivíduo acorda. Os penteados das mulheres são tipicamente africanos. Carregam quase tudo na cabeça. As crianças são carregadas em um dos quadris.

E isto é por enquanto tudo que lhe posso dizer sobre Santo Antônio. À vista deste material, que sugere o senhor?

Minhas lembranças a Mrs. Herskovits e Jean e também os amigos e colegas.

Abraços afetuosos do amigo e discípulo 0ctávio ${ }^{55}$.

Santo Antônio dos Pretos (MA), 11 de Março de 1944

Carta no 12

Caro Dr. Herskovits,

Acabo de receber há apenas alguns momentos sua carta de Fevereiro 29; estava justamente à espera dela para lhe escrever. Com toda a probabilidade, o senhor já recebeu minhas duas cartas anteriores, uma que lhe enviei de Codó e outra daqui dando-lhe minhas primeiras impressões sobre esta comunidade.

Até o dia 5 deste, segundo notícias que Dr. Teixeira me enviou de São Luís, o Banco do Brasil ainda não tinha recebido nenhuma comunicação a respeito do dinheiro da Rockefeller. Vou também escrever a ele e colocar junto uma notinha pedindo para ele lha enviar se o dinheiro ainda não tiver chegado.

A declaração de que eu pretendo continuar com a Escola de Sociologia vai junto a esta; como é compreensível, não pode ser datilografada. Espero, entretanto, que seja satisfatória. Não creio que haja alguma relação entre o tohweno e a "pequena gente" das florestas africanas. Não acho que também posso dizer o contrário. De fato, pensando melhor, lembro-me que certa

55. RR - Em 22 de março, Herskovits comenta: “Your materials on the soul couldn't be more African, as you know from Dahomean materials. With these concepts and with the delightful syncretism with the Catholic idea about the soul, I think you have something that you ought to drive for fuller details regarding, particularly details as to cult practices. It is needless, of course, for me to stress to you the importance of the economic material you sketched and you are getting more of them. I would suggest particularly that you get as definitive details of work exchanges as possible - who helps whom, and how often, and for what return, and particularly the relationships, either by blood, marriage, or residence of those who carry on cooperative work for each other" (HERSKOVITS, BOX 27, Folder 34). 
vez, numa discussão, uma vodunsi querendo exaltar a sua família de divindades e diminuir os tohweno disse que estes eram bichos que Davisse tinha transformado em gente. Com muito cuidado, inquirir a mãe-do-terreiro, mas esta negou esta origem. Talvez eu deva investigar isto melhor. Os nomes deles não lhe sugerem alguma coisa, alguma conexão com membros da família real? Dako, Apojevó, Dessé, os gêmeos Tossá e Tossé - estes são os tohweno.

Não encontrei nada semelhante ao erê a não ser as tobossi, isto é, as meninas. Já lhe disse a respeito delas, se não me engano. Erê como o senhor encontrou na Bahia - o período psicológico posterior à possessão - não existe nas casas de mina de São Luís ${ }^{56}$.

Bem, respondidas as perguntas que o senhor me faz passo a falar-lhe do que tenho encontrado aqui. Antes, entretanto, desejo pedir-lhe que numa das suas próximas cartas, agora que o senhor já tem um quadro mais ou menos completo do meu trabalho no Maranhão, me indique em que linhas devo concentrar minha atenção no prosseguimento do meu estudo em São Luís. Obtive mais informações sobre a vida econômica e a de família que ampliam o quadro que lhe pintei da situação aqui. Não creio que é necessário dizer-lhe mais a este respeito. Entretanto, se alguma pergunta importante lhe ocorrer estou pronto a respondê-las.

A vida de culto não tem nem por sombra a riqueza da casa de mina jêje de São Luís; entretanto, reveste-se de formas diferentes desta e bastante interessantes. Assisti a dois pajés, um deles na povoação de São Joaquim, o outro aqui. Para começar a sala de dança é aspergida com água a fım de afastar o "mardito" (o Diabo) e os espíritos maus. Em seguida, ajoelham-se todos, homens e mulheres, ou apenas estas, formando um círculo ou semicírculo e entoam a cantiga de chamada, uma mistura de português e africano (jêje, eu penso) em que se mencionam os nomes de Verequete, Mãe Soboa (Sogbo) e às vezes Pedro Angaço e Légua Boji. Os outros “encantados” também devem ser chamados então, mas, como me explicaram, não o são para não retardar o início das danças. Findo isto, as mulheres participantes do culto levantam-se como os outros e batem palmas (só as mulheres); a música então começa e logo principiam a dançar. Devo notar que a maneira em que se ajoelham, principalmente as mulheres - as únicas que cantam esta cantiga - é tipicamente africana, as cabeças muito inclinadas para frente a pouca distância do solo.

A orquestra compõe-se de apenas um tambor longo, de uma boca, de tornos; é preso por uma corda à cintura do tocador que usa apenas suas mãos para tocá-lo. Os outros instrumentos, vistos por mim, são o berimbau e duas ou três cabaças; em São Joaquim havia um flautista. Dizem-me que há outro instrumento, aqui pouco usado, mas importante em outros lugares - as tabocas; são dois tubos ocos de bambu de cerca de meio metro de comprimento e raio de 5 centímetros; são colocados verticalmente no solo duro e o tocador bate com as mãos espalmadas na extremidade superior produzindo um som não tão intenso como tambor mas semelhante a este ${ }^{57}$.

A música é regularmente monótona e diferente da que eu ouvi em São Luís. Há poucas variações; o mesmo diga-se da dança. Só dançam em roda e às vezes no início da possessão ou quando esta está no auge, à frente do tambor. Os passos seguem em geral o padrão do samba. As cantigas são quase todas em português; às vezes, distingue-se uma palavra africana, mas isto é raro. Em São Joaquim, depois da cantiga de chamada, cantam para Eowá e Légua Boji; seguiram cantigas em português; numa delas se mencionava o cativeiro; noutra a venda de

56. SF - Costa Eduardo destaca diferenças entre tambor de mina e candomblé.

57. SF - Interessantes as referências do pesquisador ao uso nos tambores do meio rural do berimbau, da flauta e ao tambor de taboca. 
escravos para o Rio de Janeiro. Não ouvi estas cantigas aqui, mas são conhecidas. 0 “brinquedo" dura a noite inteira e às vezes continua na manhã seguinte.

Homens e mulheres dançam. As vestes são bem extravagantes pelo nosso padrão. Quando com o santo as mulheres usam toucas brancas sobre a cabeça, blusa branca e saia de cor. Não enrolam toalha na cintura, mas algumas usam-nas, tendo-as nas mãos. Alguns homens dançam com toalha na cintura, o tronco descoberto. Outros preparam-se; os que têm "encantado mulher" vestem-se extravagantemente como tal. Outros usam gorro colorido e uma blusa sem mangas.

0 início da possessão, bastante diferente de São Luís, é caracteristicamente africano. Pela primeira vez, vi os típicos movimentos de pescoço e de ombros; alguns andam com as mãos no chão. Todos dão esturros, isto é, fazem sons roucos na garganta. Só se acalmam quando o chefe do culto ou seu auxiliar banham seus pés, mãos e cabeça com vevéu, uma infusão de folhas em que a principal é a de esturaque. Depois de acalmados e vestidos, os encantados podem cumprimentar os presentes, nem todos fazem isto, porém. Antes, entretanto, cada um que chega saúda o chefe do culto - pai ou mãe-de-terreiro; a pessoa possuída ajoelha-se e beija as mãos deste. Como eu estranhasse que os espíritos pedissem a benção deu mortal, o pai-de-terreiro daqui disse-me que isto é porque aqui na terra ele é o chefe deles. Isto é indicativo da natureza dos "encantados": são espíritos da "encantaria", vindos de Roma ou do fundo das águas e embora sejam chamados santos não se identificam de forma nenhuma com os santos católicos. Alguns deles: Manesinho, Baiano, Moça Fina, Kakamadô, Atinvorô, Trovão, além dos já citados. Légua Boji e o Diabo, bom e mal, como lhe disse anteriormente. Entretanto, nada se oferece a ele quando se faz um sacrifício para um dos outros. Sacrifício aqui conhecidos são uma vela uma galinha. Légua é cachaceiro e barulhento; vem dançar, mas não é convidado. Chegado, continua a dançar, mas em geral dança afastado da roda. Não vi ninguém possuído por ele; a mulher dele, dizem-me, mora a alguma distância daqui; esta anda a fazer algumas curas.

Até agora, não notei nenhuma ligação especial do culto destes espíritos com a vida econômica. Em relação à vida de família, sei que, por ocasião dos nascimentos, se o parto é difícil, os encantados podem vir. Não influenciam o casamento (mas por oito dias antes de um "pajé", os participantes não podem ter relações sexuais). Por ocasião de um funeral, sua presença é quase certa (para não tornar esta muito longa, deixo para minha próxima carta a descrição de um funeral que assisti).

São muitos católicos os pretos daqui, e embora a vida econômica não seja influenciada pelos encantados, está significantemente presa às suas crenças católicas. Assim, se as chuvas necessárias à agricultura estão tardando, fazem procissões percorrendo muitas vezes distâncias grandes; vão aos povoados vizinhos e deixam num deles os santos daqui enquanto os de alguma comunidade vizinha trazem seus santos para cá. Segundo acreditam, isto tem uma influência mágica na vinda das chuvas. Fora isto, não há outras crenças mágicas relativas à agricultura, exceto que os três primeiros dias da lua nova não são bons para o plantio e colheita.

Não há feiticeiros nem curandeiros aqui. No vilarejo de São Joaquim há um. Os habitantes daqui dizem que os de lá são feiticeiros; por sua vez, os de São Joaquim acusam os daqui de fazerem "porcaria". Além deste termo, usam-se feitiço e moanga (em São Luís é coioió). Uma prática de que acusam os feiticeiros é "virar bicho"; tomam em geral a forma de porco ou de jumento sem cabeça e atacam os viajantes nas estradas. 0 temor de feitiçaria é grande mas não é exagerado absolutamente.

Em relação às minhas atividades futuras aqui, penso obter mais dados sobre a vida de culto e transcrever as cantigas, bem como algumas histórias; isto não me tomará muito tempo pois tenho a impressão de que o folclore desta comunidade é pobre. De um modo geral, creio que 
com mais um mês aqui terei obtido uma ideia bastante acurada desta cultura. Assim, partirei daqui para a vila do Codó no dia 16 de Abril e irei lá vasculhar testamentos antigos, como fiz nos cartórios em São Luís, para ver se encontro documentos sobre a procedência dos escravos desta região. É interessante que embora se dê o nome de nagô ao culto religioso de origem africano, eu não tenha deparado nenhum nome de divindades iorubás.

Acha o senhor que meu plano é certo? Peço-lhe suas sugestões sobre isto e sobre o trabalho em geral. Minhas lembranças à Mrs. Herskovits. Faço meus melhores votos para Jean esteja de novo de perfeita saúde.

Abraços afetuosos do 0ctávio ${ }^{58}$.

Santo Antônio dos Pretos (MA), 24 de Março de 1944

Carta n० 13

Meu caro Dr. Herskovits,

Espero que o senhor tenha recebido minha carta anterior, bem como uma que lhe enviei do Codó e outra daqui. Até agora não recebi notícias suas acusando o recebimento de nenhuma mas isto é muito provavelmente devido à demora da correspondência em me alcançar aqui no mato.

Meu trabalho está quase findo aqui. Obtive o que, ao que me parece, havia para colher a respeito da vida econômica, da vida de família e da religião. Estou agora lutando para obter histórias; isto tem sido bem difícil porque meus informantes só consentem em contar histórias à noite pois quem as conta durante o dia é mentiroso. E ninguém quer ser mentiroso! Demais, não é todas as noites que tenho informantes à minha disposição. Assim, isto está se tornando um pouco difícil e...demorado. E como a maioria dos dados que eu tinha de obter já estão no saco pouco tenho a fazer durante o dia; minha estada aqui está assim se tornando monótona e enfadonha. Entretanto, não sei ainda se seria prudente partir daqui para o Codó imediatamente pois que faltam apenas 10 dias para a Semana Santa (de 2 a 9 de abril) e durante esta os pretos daqui se reúnem na "casa grande" para contar histórias; no Sábado de Aleluia talvez tenha um pajé. Ainda não estou bem certo se conviria ou não eu ficar para ver estas coisas. Se eu não obtiver até então um número razoável de histórias é quase certo que ficarei.

Tenho escrito histórias de Pedro Malazarte, de João e Maria, de reis e rainhas e de animais. Estas são principalmente sobre o coelho e a onça; esta última, "Minha Tia Onça”, é sempre enganada pela astúcia do primeiro. Como lhe disse, parece-me que o folclore do povo daqui é pobre; até agora não mudei de opinião mas só depois de escrever uma porção considerável de histórias é que poderei dizer alguma coisa defınitiva.

Na minha carta anterior, disse-lhe a respeito de Légua Boji coisas que não são verdadeiras. Depois de muito cuidado, ao inquirir, descobri que não fazem aqui a identificação dele com o Diabo; não obstante, ele tem os característicos do trickster que o diferenciam dos demais encantados; é cachaceiro, barulhento e castiga os que dele fazem pouco. É bom para serviço mais pobre do que não lhe "paga" o que lhe promete; leva-o para dentro de espinheiros, fá-

58. RR - Em 15 de Abril de 1944, Herskovits declara: "The term moanga used for the magic charm interests me very much, since it is practically identical with the term wanga used in Haiti to express the same concept. I suspect it is a name of Congo provenience. As to the relationship between the tohweno and the 'little people' of the African forest, I do not doubt that you did not find any since I carelessly substituted that term for the one tohosu" (HERSKOVITS, BOX 27, Folder 34). 
lo subir em árvores altas, espojar-se na lama ${ }^{59}$, e chegam até a responsabilizar a morte de um homem aqui $[. . .]^{60}$

São Luís (MA), 13 de Abril de 1944

Carta no 14

Caro Herskovits,

Aqui estou eu de volta a São Luís depois de dois meses em Santo Antônio dos Pretos. Várias razões fizeram-me voltar. Em primeiro lugar, creio que conclui mais ou menos satisfatoriamente meu trabalho lá. Infelizmente os dez últimos dias de minha estada foram quase inteiramente perdidos; adoeci bastante com uma gripe que me prostrou, perdi algum peso e fiquei bem abatido. Assim, não me foi possível, como era minha intenção, colher um número de histórias que fosse satisfatório; não obstante, escrevi umas vinte e a amostra não me parece má. Infelizmente, a Semana Santa não transcorreu como de costume. Havia muita gente gripada, uma verdadeira epidemia. Não se reuniram na Semana Santa para guardar o senhor morto, nem tampouco realizaram o ritual para "romper a aleluia". Assim, a gripe feriu o progresso do meu trabalho de ambos os lados. Além desta razão, foi-me necessário ir à cidade do Codó devido a um "convite" do Delegado de Polícia, um pobre idiota, para preencher "certas formalidades legais" muito embora eu tivesse, por palavras e documentos, esclarecido os motivos de minha presença na região. 0 prefeito queria saber o que eu estava fazendo. Foi tudo muito aborrecido para mim mas as coisas se esclareceram bem. Hoje, estive com o Consultor Jurídico do Estado, meu amigo, e amigo do Interventor, a quem contei todos os incidentes desta aventura pitoresca. Avistar-me-ei com o interventor, segundo ele me prometeu, e lhe pedirei uma carta dirigida aos prefeitos do interior pois é minha intenção voltar ao Codó muito breve. Aliás eu teria ficado lá se o cheque que o senhor me remeteu já tivesse me alcançado. Mas, de uma certa forma foi bom eu ter vindo para São Luís; estava e ainda estou bastante cansado (embora o trabalho não seja duro!), e um pouco abatido da gripe. Aqui posso me tratar adequadamente e ter uma dieta melhor e um pouco de fun. A solidão entediou-me algum tanto e um "banhozinho de civilização" não me fará mal.

0 dia da minha partida para o Codó está, entretanto, subordinado ao recebimento do dinheiro. Ainda tenho algum, mas não é muito. É meu pai que tem sido o Rockefeller nesses dois últimos meses. Infelizmente sua carta de 11 de Março só me alcançou no dia $1^{\circ}$ deste, quando eu estava gripado; seu cabograma do dia 10 foi-me enviado imediatamente pelo Dr. Veras mas nunca me foi entregue; ontem, consegui uma cópia como a Western aqui; logo à noite lhe enviarei um

59. SF - Interessantes as observações de Costa Eduardo sobre Légua Boji Bua, que até hoje permanecem. 60. RR - Não foi possivel encontrar o restante da carta nos arquivos da Northwestern University. Em 27 de Abril de 1944, Herskovits diz: "What you say about your work continues as interesting as ever. The types of tales you are gathering seem to be the standard ones, but both Mrs. Herskovits and I enjoyed the explanation of why the Santo Antonio people don't want to tell them in the daytime. I suggest you check this point and find out if there isn't another reason associated with the fear of the dead. The collection should be important data in rounding out distribution and will probably make a substantial publication in itself. The characteristic of Legun Bori are quite in line with what one would expect in the light of African and other New World Negro characteristics. I think that just about solves that problem for the interior, at least, and it should give you leads for tackling it in São Luis. The description of the funeral that you give is again quite interesting and also quite in pattern. I take it that they don't have anything that compares to the Bahian sihun" (HERSKOVITS, BOX 27, Folder 34). 
cabograma pedindo que cancele o cheque e me envie o dinheiro por cabograma. Assim, minha presença aqui também porá fim a este jogo de esconde-esconde entre o dinheiro e mim.

Quero aqui agradecer-lhe, de todo coração, seu genuíno interesse nas minhas futuras relações com Escola de Sociologia. Foi-me muito grato também saber que a Universidade me concederá um "tuition scholarship".

Eu me congratulo sinceramente com o senhor e felicito pela aceitação do seu projeto educacional pela Faculdade da Universidade; estou certo de que Northwestern será de fato um curriculum às direitas. Também fiquei contentíssimo em saber que é [Alfred Irving] Hallowell possivelmente aceitará um lugar no Departamento de Antropologia. Eu gostarei imenso de vir a estudar com ele.

Sua carta de 22 de Março estava à minha espera aqui. Fiquei, naturalmente, satisfeito com os termos a que o senhor se refere aos meus achados no interior. Quanto a visitar outras comunidades, pensei sim em fazê-lo; mas se pensei e tive a intenção, não fui muito além disto. Entretanto, informações que obtive autoriza-me a dizer que Santo Antônio é um retrato fiel das outras. Julguei assim que eu deveria em vez de visitar outras comunidades do mesmo tipo fazer algumas observações no Codó; ainda continuo a pensar que seria interessante voltar ao Codó pelo menos por duas semanas. E agora com sua sugestão, estou pensando que não seria mau, se eu tiver tempo de visitar, ir por alguns dias a outra comunidade rural na zona de Codó ou Coroatá. Esta vila está também situada na Estrada de Ferro, 60 quilômetros aquém de Codó. Estes são os planos, mas, parece-me, a fim do trabalho em São Luís não ser prejudicado que, por enquanto, devo limitar-me ao Codó.

Fiz a viagem de volta de Santo Antônio ao Codó a cavalo num dia só, cerca de 9 horas ininterruptas de viagens. Sofri um bocado, mas não tanto quanto da primeira vez. Grato pela simpatia sua e de Mrs. Herskovits. Dei boas gargalhadas com a resposta tão característica, como o senhor diz, de Mr. Snyder. E por que não haveria Northwestern de ter um time de polo: "it's a fine thing to have!".

Hoje, limito-me a estes assuntos. Breve escrever-lhe-ei com detalhes a respeito do meu trabalho. 0 senhor recebeu as cartas que lhe enviei de Santo Antônio? Infelizmente, nem sempre eu conseguia arranjar um bom portador. Continua a ser uma pena que minhas cartas demorem tanto em lhe chegar às suas mãos. Minhas melhores lembranças a Mrs. Herskovits e Jean.

Abraços afetuosos do Octávio.

São Luís (MA), 20 de Abril de 1944

Carta no 15

Meu Caro Dr. Herskovits,

Seu cabograma chegou anteontem à tarde, mas só hoje pude receber o dinheiro (ontem foi feriado, aniversário do Presidente). Na minha carta anterior, expliquei-lhe a razão da minha demora em me comunicar a este respeito com o senhor. Muito obrigado pela presteza com que o senhor atendeu o pedido do cabograma que lhe enviei.

Naturalmente, o senhor teve despesas enviando-me dois cabogramas. Peço-lhe, por favor, que o senhor desconte da próxima remessa o dinheiro gasto. Eu desejaria pedir-lhe dois outros favores: $1^{\circ}$ ) que me comprasse e enviasse, por via aérea, caso não for um despropósito, dois rolos de filme para câmera Leica ou Contax; 20) que pedisse à Society of the Sigma Xi para me continuar enviando os números da American Scientist. Eu lhe pediria que o senhor descontasse todas essas despesas da minha próxima remessa. Creio ser melhor o sr. enviá-la em meados 
do próximo mês para evitar que aconteça a mesma viagem inacabável desta última remessa. Desejo os filmes para tirar algumas fotografias de páginas de inventários antigos em que há informações sobre escravos (infelizmente, não poderão ser muitas) e outras fotografias. Mas, se for difícil achar os filmes ou enviá-los, não se incomode. Quanto ao American Scientist, creio que qualquer dos membros do Chapter daí lhe poderá dar informações. Grato por tudo e desculpe eu ser tão aborrecido.

Faz nove dias que estou em São Luís; já reestabeleci alguns dos meus contatos, principalmente com as minas (jêje) e nagô. Receberam-me todos muito bem. As primeiras esperavam-me com o nome jêje deixado pelos voduns para mim. Eu sou de Danbirá, filho de Podiboji (por causa da velha Mãe Andreza) e meu nome é Bosso Hõdokhuê; Bosso denota Danbirá ou Davisse. Hõ denota Zomada e dokhuê quer dizer que eu sou da casa, filho da casa ${ }^{61}$. Cada pessoa do grupo tem seu nome jêje dado pelos voduns; é por este nome, e não pelo seu verdadeiro, que é chamada por eles. E na Casa de Nagô, guardaram-me pipoca e azogri do avambã da quarta-feira de cinzas. Parece que não se esqueceram de mim, como o senhor vê.

Meu antigo informante José Siqueira, que tinha desaparecido semana antes da minha partida, reapareceu. Quer com ele ou com as pretas acima, tenho procurado verificar algumas coisas do interior: ideias a respeito da alma humana, maneiras dos voduns se retirarem, banhamento das pedras, detalhes referentes a costumes mortuários. 0 anjo da guarda é visto da mesma forma que no interior, ao que parece; nas minhas investidas preliminares, a alma também aparece como a entidade que dá vida ao corpo e abandona-o à noite viajando. Em Santo Antônio não percebi nenhuma relação entre o anjo da guarda e o culto dos encantados. Ainda não sei se haverá alguma coisa aqui. Diferentemente da Bahia, o anjo da guarda aqui não é espírito africano; isto é verdadeiro para Santo Antônio; para São Luís, ainda não é uma conclusão definitiva.

Na sua carta do dia 22, o senhor acentua a importância de obter o maior número possível de dados sobre a vida econômica. Creio que obtive uma porção razoável. A cooperação no trabalho depende muito da fase agrícola; durante a derrubada das árvores e a roçagem, é máxima; durante a limpeza, há muitos que preferem trabalhar sós; na época da colheita, também cooperam bastante. 0 dia de serviço é trocado por dia de serviço. Residência, quero dizer vizinhança, não desempenha nenhum papel na troca de dias. Mas laços de família têm importância. Irmãos trocam dias entre si, mãe e filha fazem o mesmo. É costume escolher um amigo íntimo para companheiro de trabalho; mas, às vezes, quando o homem quer reunir um grupo grande (6 ou 7) escolhe alguns que são apenas mais ou menos seus amigos. Pareceu-me também que os mais jovens escolhiam os mais novos, e os mais velhos os de sua geração.

Devo partir, segunda-feira (24) para o Codó onde ficarei duas semanas. Se o senhor achar que meus planos estão um pouco errados, por favor escreva-me logo. Lembranças a Mrs. Herskovits e Jean.

Sou com um forte abraço, o discípulo e amigo muito grato, Octávio.

61. SF - Interessante o recebimento de um nome africano e a explicação do significado. De fato na Casa das Minas cada pessoa tem um nome jeje dado pelos voduns, mas não é de meu conhecimento que continuaram dando nome a outros pesquisadores. 
São Luís, 12 de Maio de 1944

Carta $n^{\circ} 16$

Meu Caro Herskovits,

Acabo de chegar do Codó onde passei 15 dias. Infelizmente, num período breve como este só pude fazer uma sondagem da situação, não estudo mais alentado como gostaria de fazer. Fundamentalmente, os mesmos padrões culturais característicos de Santo Antônio dos Pretos se aplicam ao Codó. Esta é uma cidade de 6.000 habitantes, metade dos quais, pelo menos, de cor. Destes, uma parte constitui uma população semi-rural pois possuem pequenas roças onde vivem na época da colheita e limpeza. A organização familiar segue a linha tão nossa conhecida. A vida de culto na cidade está desorganizada. Há 5 ou 6 anos atrás, havia três terreiros mas atualmente não há nenhum; perguntados, meus informantes deram várias razões: perseguição da polícia, falta de dinheiro, falta de mães e pais-de-terreiro, dissensões entre os membros mais proeminentes do culto. Entretanto, realizou-se um "brinquedo" para eu ver. Tudo teve de ser improvisado. Mas foi um sucesso. Havia pelo menos 250 pessoas assistindo e 10 participantes. As danças começaram às 1 e $1 / 2$ do sábado e foram até às 6 horas da tarde do domingo. Orquestra: 1 tambor de uma boca, 2 marimbas, 3 cabaças, 1 ferro. Cantigas em português, algumas com termos africanos. Espíritos mais conhecidos: Légua Boji e Pedro Angaço. Outros: Verekete, Rainha Rosa, Vaqueiro. Vevéu para banhar as mãos ao entrar no terreiro e para banhar a cabeça dos iniciados ao receber seus espíritos. Como não têm terreiro, não têm assentamento. Não conhecem. Disse um velho de 65 anos, antigo dono do terreiro: "o assentamento é a base fundamental; não tendo, tudo é matatempo". Não há rituais tipicamente africanos ${ }^{62}$.

Achei sua carta de Abril 15 muito noticiosa e interessante. Estou contentíssimo por saber que o Dr. Hallowell irá mesmo para aí! ${ }^{63}$ Não sabia que o Dr. Campbell é "a pround father". Se estiver com ele e a senhora, faça-me o favor de cumprimentá-los em meu nome. Ray Bauer foi finalmente chamado. E Alice, continuará aí? Dos Kings há muito que não tenho notícias. E Dick, como vai? Lembranças a Hampton quando lhe escrever.

Seu comentário sobre moanga e uranga é corretíssimo. Este último termo e muamba são usados pelos pretos garimpeiros de Diamantina, em Minas Gerais. Segundo diz Aires da Mata Machado Filho, em 0 negro e o garimpo em Minas Gerais, $42^{\circ}$ volume da coleção Documentos Brasileiros ${ }^{64}$. Escrevi um "book-review" deste livro enquanto no interior mas não sei se o publicarei porque fui um pouco cáustico. De qualquer forma, vou tirar uma cópia para lhe mandar.

0 cheque do State Bank chegou-me às mãos, finalmente. Demorou 3 meses pelo caminho porque, por descuido da tesouraria da Universidade, eu penso, foi enviado pelo correio comum e não por via aérea. Segue junto a esta. Também recebi, vindo de Wisconsin, seu "An outline of Dahomean Religious Belif" ${ }^{65}$ que será muito útil, estou certo. Ontem, ainda recebi suas publicações e já as entreguei ao Dr. Teixeira e ao Dr. Lopes; ambos ficaram contentíssimos e disseram-me que vão escrever-lhe agradecendo. A. Lopes vai mandar-lhe, disse-me, uma breve nota sobre os termos mina e cacheo. Este último, disse-me, refere-se a escravos vindos da Guiné Portuguesa, certo?

62. SF - Interessante em Codó terem realizado um festa ou brinquedo para o pesquisador visitante.

63. RR - A. Irving Hallowell (1892 - 1974), discípulo de Franz Boas, especialista na etnia Ojybwa, interessado nas interfaces da estrutura de personalidade e de padrões culturais, lecionou no Department of Anthropology da Northwestern University durante os anos letivos de 1945 a 1948.

64. RR - Cf. MACHADO FILHO (1943).

65. RR - Cf. HERSKOVITS (1933). 
Ontem escrevi a Berlinck dando-lhe conta da minha viagem ao interior, mas não toquei no assunto das minhas futuras relações com Escola; até agora ele nada me escreveu sobre isto. Há alguma coisa de novo este respeito?

Reli cuidadosamente seu estudo sobre a família afro-baiana ${ }^{66}$. 0 comentário de Renê Ribeiro, que eu não conheço infelizmente, é bom ${ }^{67}$. Ele apenas se esqueceu do termo popularmente usado para mancebia, amigação. 0 "rejoinder" de Frazer merece piedade ${ }^{68}$. 0 que ele disse sobre a preposição "de" é incompleto; denota qualidade, sim, mas o possessivo também; isto qualquer principiante na língua sabe; só ele é que não! Ele nunca deveria ter citado Landes e Carneiro. Presumo que o senhor vai responder ao tal "rejoinder". Gostaria de receber um exemplar; e também gostaria que me reservasse um do artigo sobre Boas, e outros sobre este como o "rejoinder".

Aqui, em São Luís, temos agora a Festa do Divino Espírito Santo, dos dias 18 a 28. Dar-lheei notícias. Lembranças a Mrs. Herskovits e Jean.

Com um forte abraço, sou amigo e discípulo Octávio.

Esta carta já tinha sido escrita quando me foram entregues pelo Dr. Veras suas duas cartas, a $1^{\text {a }}$ de 27 de Abril e a $2^{\text {a }}$ de 4 destes.

Surpreendeu-me bastante saber que Jean teve que se submeter a uma operação súbita, mas alegro-me por saber que ela já esteja completamente restabelecida. E que continue assim; imagino o susto que Mrs. Herskovits e o senhor tiveram.

Alegraram-me as notícias sobre a carta de Berlinck ao senhor. E é ótimo que Dick W. continue aí.

Eu felizmente estou agora gozando de boa saúde. Quando fui para Codó ainda tinha muita dor de garganta mas a inflamação cedeu depois de poucos dias.

Desta vez não tive aborrecimentos com as autoridades; o delegado até me auxiliou a arranjar o tambor de mina para eu ver!

Estou escrevendo à Dona Heloísa e também a Pierson sobre minha estada no interior. À primeira escrevi duas cartas (ou mais) desde que aqui cheguei; ela nunca me respondeu sequer uma linha.

Creio que os trechos abaixo do que escrevi sobre o livro de Machado Filho lhe interessarão:

"No município de Diamantina em Minas Gerais, alguns povoados de garimpeiros, entre os quais São João da Chapada e Quartel de Indaiá, habitados principalmente por negros de origem banto. Como descendentes de africanos, sua cultura conserva muitos aspectos tipicamente africanos. Quando trabalham na mineração, entoam cantigas chamadas de vissungos em língua ambundu (banto) pura ou modificada e misturada com português. Essas cantigas, a letra e a música de muitas das quais são transcritas, o autor nota "estão quase desaparecendo" (p.62). Creêm intensamente em magia e explicam muitos aspectos de sua vida diária em função dela; denominam-a pelos termos de mandraca e muamba, esta última uma palavra de origem banto quase idêntica com o termo moanga usado no interior do Maranhão.

0 termo uanga, também registrado, é como os pretos do Haiti denominam os seus feitiços (informação recebida por carta do Prof. Melville J. Herskovits). Alguns costumes católicos como o do "contrariar" os santos, também observado no interior do Maranhão, têm um sabor tipicamente africano. Muitos vocábulos bantos são conservados nesta região e o autor os registros

66. RR - Cf. HERSKOVITS (1943b).

67. RR - Cf. RIBEIRO (1945).

68. RR - Cf. FRAZIER (1943). 
nos dois capítulos finais do livro, "Vocabulário do dialeto crioulo sanjoanense" e "Vestígios do dialeto crioulo no linguajar local”, uma boa contribuição aos estudos de linguística africana no Brasil, embora a transcrição das palavras não seja fonética. Opina o sr. Machado Filho, baseado nestes achados linguísticos, pela existência nesta região de um dialeto crioulo banto a exemplo da língua geral africana - nagô - que existiu na Bahia (p.114)”.

As manifestações culturais que vêm de ser indicadas em uma discussão sobre termos da vida da mineração e sobre a forma de trabalho nos garimpos são quase tudo o que encontramos neste livro.

0 resto é crítica: o que mais podia ser feito e minha opinião porque o autor parou aí: falta de treino profissional, sendo ele um etnólogo amador, dedicado e brilhante, mas ainda um amador. E aponto a necessidade de formarmos etnólogos. Como lhe disse, não sei se publicarei isto.

Desejo-lhes muita felicidade com o victory garden. Talvez eu ainda chegue a tempo de comer uns rabanetes!

Estou reiniciando minhas atividades aqui. Hoje, para comemorar o 13 de Maio, irei dançar um pouco no "Hotel Central" ao som de uma orquestra americana de marinheiros, a "The Admiral's band”. Estou saindo um pouco, como vê, do meu programa antropológico.

De novo, um abraço do Octávio.

São Luís, 6 de Junho de 1944

Carta no 17

Caro Dr. Herskovits,

Seguem junto quatro pequenas fotos ${ }^{69}$.

Suas duas cartas, a primeira de 18 de Maio e a segunda de 24, chegaram-me às mãos. As notícias que o senhor me dá são ótimas e fazem-me muito feliz. Agradeço-lhe sinceramente por todos os esforços que tem feito para me proporcionar mais um ano de estudos em Northwestern e eu tenho certeza que esta temporada além de ser de grande significação para meu trabalho será um grande prazer pois permitirá que eu reveja a América e todos meus bons amigos. Suas palavras, muito bondosas e animadoras, encorajam-me e eu sou sinceramente grato pela confiança com que o senhor me tem distinguido.

É bom saber que a Fundação aumentou o "grant" o que, sem dúvida, me permitirá uma vida mais folgada. E por falar em dinheiro, já recebi o último que foi enviado por cabograma.

0 schedule que o senhor delineou para os próximos meses vem ao encontro dos meus desejos. Sinto conveniente passar ainda três semanas aqui e assim espero partir dia 26. Penso que sua sugestão para que eu passe alguns dias em Recife e Bahia vem muito a propósito e é minha intenção ficar até o dia $1^{\circ}$ de Julho no Recife e passar 5 ou 6 dias na Bahia.

Ontem falei com o agente da Panair e pedi-lhe para me arranjar as passagens de acordo com este programa. Terei logo a resposta e espero que tudo dê certo. Assim deverei estar no Rio pelo dia 6 ou 7 de Julho. Irei procurar Dr. Crawford imediatamente. À Dona Heloísa, vou escrever anunciando minha chegada ao Rio e o "grant" da Fundação. Naturalmente, irei vê-la no Rio.

No tocante à minha ida, a maior dificuldade parece ser a licença do Ministério da Guerra para me ausentar do país, mas tenho muita esperança de que isto também se resolverá satisfatoriamente.

69. RR - Três delas reproduzidas em anexo. 
Quanto à passagem, não será necessário que o senhor envie o dinheiro. 0 agente da Panair aqui acha que eu terei tempo de sobra para tratar da passagem no Rio e disse-me que o pagamento pode ser feito aí nos Estados Unidos; desta forma, seria bom que o pagamento fosse feito aí na época oportuna, ou seja, na segunda dezena de julho.

Sobre meu trabalho, não lhe anuncio nada fundamentalmente novo; as festas ao Divino Espírito Santo estão terminando. Uma descrição dessas festas e alguns comentários sobre costumes mortuários das "nagoenses" seguem junto a esta. Tenho checado (do inglês "checked") alguns pontos e ampliado outros, mas em geral não fiz novas descobertas. Minha gente tem estado preocupada com o Divino e é só do que tratam. De outro lado, chuvas constantes e enervantes têm-me atrapalhado um pouco.

De saúde, não tenho estado do mal, mas também não tenho estado bem. Ultimamente, devido ao tempo chuva e calor imenso, tenho estado ou gripado ou resfriado. Agora é a garganta e os médicos descobriram-me uma doença com um nome bonito - angina pultácea - mas é coisa passageira e nada grave.

Eu folgo em saber que Jean está bem e faço meus melhores votos que o senhor e Mrs. Herskovits tenham um verão agradável.

0 senhor poderia me dizer quando partem os Kings para Califórnia?

Grato por tudo e esperando revê-lo em princípios de setembro sou o discípulo e amigo Octávio.

P.S. Acabo de ouvir as primeiras notícias sobre a invasão pela qual havia aqui uma expectativa geral.

O povo tem estado em festas, as Festas do Espírito Santo. Tenho-as acompanhado e obtive uma boa visão da sua significação e importância. É uma festa de fundo católico, mas de cunho eminentemente popular. É interessante notar que os grupos que a realizam são em grande parte, senão na maioria, constituídos por pessoas que pertencem à tradição africana. Fazem a festa as jêje e a gente de mais duas casas de mina; faziam-na as nagô, mas de algum tempo a esta parte deixaram de fazê-la. Alguns curadores também realizam a festa.

Os grandes dias da festa são a Quinta-Feira da Ascensão, o Domingo do Divino e a segundafeira seguinte. Mas desde o Domingo da Páscoa, digo Ressurreição, a festa se prenuncia. Num altar, dedicado ao Divino, colocam a pomba e a coroa que o representam. Todos os domingos, a partir deste acima, o Divino é aí homenageado por um grupo de mulheres, caixeiras, que tocam caixa; a caixa é um tambor de duas bocas, leve, com um corpo de uns 40 centímetros de comprimento e produz um som ruidoso. Não tem nada do som batido dos atabaques. As caixeiras tocam com varetas e cantam cantigas de louvor ao Divino. Num domingo, um longo madeiro roliço é trazido para casa da festa; é o mastro. Na Quinta-Feira da Ascensão, ele é levantado no quintal. Na sua extremidade superior colocam a pomba do Divino e uma bandeira em que está bordado ou pintado uma pomba; a ocasião é festiva e a casa enche-se de gente. 0 mastro, a bandeira, outras bandeiras, as caixas, tudo isto é batizado.

No Domingo do Divino, uma missa cantada é oferecida ao Divino. Finda esta, organiza-se uma procissão para a casa da Festa. Vêm as caixeiras tocando e cantando, gente, e à frente crianças com bandeiras do Divino e os "impérios", isto é, quatro crianças, dois meninos - um vestido como imperador do Divino e outro como seu mordomo real - e duas meninas - uma a imperatriz do Divino e outra a sua mordoma real. 0 imperador e imperatriz trazem em suas mãos a pomba e a coroa do Divino.

A entrada na Casa da Festa é triunfal; o imperador distribui presentes de carne a alguns mendigos que foram convidados de antemão. Então, vão todos juntos ao mastro e aí cantam. 
Durante o dia inteiro há festas. Dançam batucada, cantam e tocam para o Divino. A casa distribuir comida. Na segunda-feira, à noite, derrubam o mastro ao som do toque das caixas e cantigas; é tudo muito festivo. E a festa termina com "fechamento da tribuna", isto é, as cantigas e cerimônias que têm lugar junto ao altar do Divino.

Esta é em resumo a festa do Divino Espírito Santo. Que é uma das mais importantes, não há dúvida. 0 Divino, entidade fecundadora, é grandemente cultuado. É o Pai Eterno, dizem muitos. E para as jêjes é Evôvodum, nome que também se dá a Jesus. É maior que todos os voduns e estes lhe devem culto. Alguns destes possuem suas filhas e vêm presenciar a festa. Uns servem de padrinho ao mastro ou alguma caixa. Quanto à significação do mastro, este representa a cruz em que Jesus foi crucificado ${ }^{71}$.

Obtive uma descrição satisfatória das cerimônias funerárias nagô, as fases principais das quais eu transmiti ao senhor há tempo. Alguns objetos das mortas são na $1^{\text {a }}$ noite conduzidos ao mar, é a carga. Não há confusão com o oferecimento placativo a Lebara. Durante as sete noites, em que estão "de nojo", as nagôs dormem no chão sobre esteiras, todas juntas. A alma da que se separa vem receber sua carga, e a entrega desta não pode ser adiada sob nenhuma circunstância; $[. . .]^{72}$.

São Luís (MA), 24 de Junho de 1944

Carta no 18

Caro Sr. Herskovtis,

Este é o penúltimo dia que passarei em São Luís e quando o senhor se receber esta carta eu provavelmente já estarei em São Paulo. Tomarei o avião de amanhã à noite, para Recife, e lá estarei até o dia 29; nesse dia embarcarei para Bahia aí ficando até o dia 2 de julho. Nestes breves dias que vou passar em Recife e São Salvador, procurarei ver algumas cerimônias e visitar algumas casas de culto. Estou contando com a boa vontade de Gonçalves Fernandes e Renê Ribeiro e do chofer Raimundo.

Logo que chegar ao Rio procurarei Dr. Crawford ${ }^{73}$ e, espero que, então, ele já tenha recebido a carta que o senhor ia lhe enviar segundo me escreveu. Com o auxílio dele, creio que o de que eu precisar se resolverá satisfatoriamente. Estou fazendo minhas despedidas.

Fiz boas amizades entre os pretos e eles parecem sentir que eu me vá embora; de outro lado, já fiz minha despedida oficial ao Interventor. Sinto-me contente em voltar para casa e minha família parece estar ansiosa à minha espera.

Nestes últimos dias aqui, tenho continuado com minhas visitas aos pretos e procurado obter informações sobre questões ainda não totalmente esclarecidas como a iniciação. Esta é aqui extremamente simples e não tem nada da elaboração baiana ${ }^{74}$.

Em São Paulo, eu poderei ser alcançado através da Escola de Sociologia. Informei Pierson e Berlinck do "grant" e também Dona Heloísa. Hoje, recebi uma carta de Pierson, mas ele não menciona minha carta e assim penso que não a recebeu. Pierson mandou-me uma cópia

70. SF - A descrição da festa do Divino é compacta, mas se refere a seus numerosos detalhe. 0 termo Evovodum para o Pai Eteno e para Jesus é usado até hoje.

71. RR - Não foi possível encontrar o final desta carta nos arquivos da Northewestern University.

72. RR - Trata-se de Rex Crawford, Cultural Relations Attaché na Embaixada Norte-Americana no Rio de Janeiro.

73. SF - Observações pertinentes sobre diferenças entre a iniciação no candomblé e no tambor de mina. 
da carta que Mr. Evans lhe enviou a propósito do "grant". Minhas muitas saudades a Mrs. Herskovits, Jean e amigos.

Um abraço muito amigo e best good [...] do Octávio.

São Paulo (SP), 10 de Julho de 1944

Carta no 19

Meu caro Doutor Herskovits,

Cheguei à São Paulo vários dias atrás, tendo feito boa viagem. Parei três dias em Recife, três na Bahia e dois no Rio de Janeiro. Em Recife, vi Renê Ribeiro e Gonçalves Fernandes. 0 primeiro especialmente foi muito gentil. Na Bahia, estive com Thales de Azevedo e Isaías Alves. Infelizmente só encontrei o seu chofer Raimundo no último dia; tratou-me esplendidamente e levou-me para ver Procópio e Vidal. Não pude ver nenhuma cerimônia pois nenhuma se realizou. Em Recife, não há casas abertas, como o senhor provavelmente sabe. Renê Ribeiro levou-me a uma preta, Sebastiana, filha de santo do célebre Pai Adão, que morou em Lagos; seu conhecimento do culto surpreendeu-me.

No Rio, visitei Dona Heloisa. Recebeu-me muito bem; creio que somos "pals". Ela esteve bem doente e seu aspecto não é bom; seu cabelo está bem grisalho. Vi também Dr. Crawford e almocei com ele uma vez. Muito gentil. Entretanto, deu-me a entender que não poderia me ajudar de modo eficiente.

Em São Paulo, não encontrei novidades. [...] está para voltar para a Inglaterra. Berlinck e Pierson mostraram-se satisfeitos com minha volta. Roger Bastide procurou-me ontem e eu lhe falei sobre o Maranhão. Miller tem estado acamado por cerca de um mês agora; ele é pai de uma meninazinha.

Encontrei minha família bem e com planos e se mudar para a cidade de Rio Preto. Maria Eugênia está trabalhando em São Paulo; sábado passado ficamos noivos oficialmente.

Ainda não sei os passos necessários para arranjar prioridade. Antes devo conseguir licença do Ministro da Guerra para me ausentar do país. Fiz a ele um requerimento e estou à espera de resposta. Tê-la-ei por estes próximos dias e tratarei imediatamente de arranjar a prioridade. Obtida esta, avisá-lo-ei a fim de que o senhor me faça o favor de pagar a passagem aí.

De saúde, infelizmente, não vou bem. A viagem ao interior do Maranhão maltratou-me e eu nunca consegui me refazer. Não me sentia bem desde aquela época. Agora, os médicos aqui descobriram que eu tenho amebas e uma complicação no baço (spleen). Estou sob tratamento severo.

Seu artigo sobre o negro no Rio Grande do Sul ${ }^{74}$ está na Revista do Arquivo desde o começo do ano. Até agora nenhum número saiu este ano. A tradução parece não ter ficado má; mandei uma cópia a Dante de Laytano e ele gostou imensamente do artigo; também disse que a tradução passava.

Arthur Ramos publicou Introdução à Antropologia Brasileira, primeiro volume, um trabalho de pesquisa bibliográfıca. Ainda não o li... A primeira parte é dedicada ao indígena, a segunda às culturas negras africanas; ele estuda uma por uma.

Esqueci-me de dizer que estive como Frei Fidélis na Bahia. Ele me proporcionou uma tarde encantadora. Por onde eu andei todos têm muitas lembranças e saudades do professor, da Dona Frances, de Jean. Eu espero que estejam tendo um belo período de férias.

Com muitas lembranças a Mrs. Herskovits e Jean, um abraço do Octávio.

74. RR - Referência ao artigo "The Southernmost Outposts of New World Africanisms" (1966 [1943]). 
Bebedouro (SP), 10 de agosto de 1944

Meu caro Dr. Herskovits,

Recebi com muito agrado suas cartas de 5 e 14 de Julho. Quando a primeira chegou, ainda estava em São Paulo e havia poucos dias antes de escrito; espero que esta carta lhe tenha chegado as mãos. Recebi sua carta de 14 de Julho aqui no interior, onde estou passando uns dias com minha família e procurando restabelecer-me. Parece que estou melhor.

Partirei para São Paulo dia 14 a fim de ultimar os preparativos para minha viagem. Infelizmente, até agora não obtive nenhuma resposta ao requerimento pedindo licença para me ausentar do país e isto está me preocupando um bocado. Se nada for resolvido até o dia 20, irei ao Rio e verei então como se pode obter imediatamente uma solução satisfatória. É estranho que até agora nada tenha sido resolvido pois meu pedido está muito bem amparado.

Peço-lhe que pague aí minha passagem. Parece que será muito difícil arranjar prioridade. A Panair, entretanto, reservou-me uma passagem para o dia 14 de setembro. Foi o melhor que pude obter. Não será necessário senhor enviar-me dinheiro daí. Terei muito prazer em ver os preços da Brasiliana e outras séries que possam interessar. Por falar em livros, os nossos editores em São Paulo estão muito receosos da concorrência que os livros escritos em português e editados nos Estados Unidos venha lhes fazer e já estão pedindo ao governo que faça alguma coisa para protegê-los. Fato é que os livros estão por um preço exorbitante. Sinto muito que Jean tenha tido de se sujeitar a uma nova operação. Espero que ela já esteja boazinha e que esta seja a última. A ela e Mrs. Herskovits minhas melhores lembranças.

Estou aqui em casa há pouco mais de duas semanas e tenho passado como um lorde. Os dias têm passado depressa demais, o que é uma pena. Maria Eugênia está em casa da irmã e nós nos temos divertido muito.

Além de ler coisas bem variadas, tenho acompanhado a guerra com particular ansiedade. Estou numa fase de grande otimismo, o que, penso, as boas notícias justificam. Peço-lhe que não se preocupe com a minha viagem; provavelmente estarei aí antes do dia 20.

Gostei de saber das boas notícias de Bascom, Dick e Virginia e Dick e Audrey. É pena, para mim especialmente, que os King tenham ido; vou sentir falta deles quando estiver aí.

Com grande abraço, sou discípulo e amigo sempre grato, Octávio. 
Figura 1 - Família de Dambirá, no fundo outros voduns. Com lenço na cabeça, voduns do sexo feminino Jan. 6. 1944.

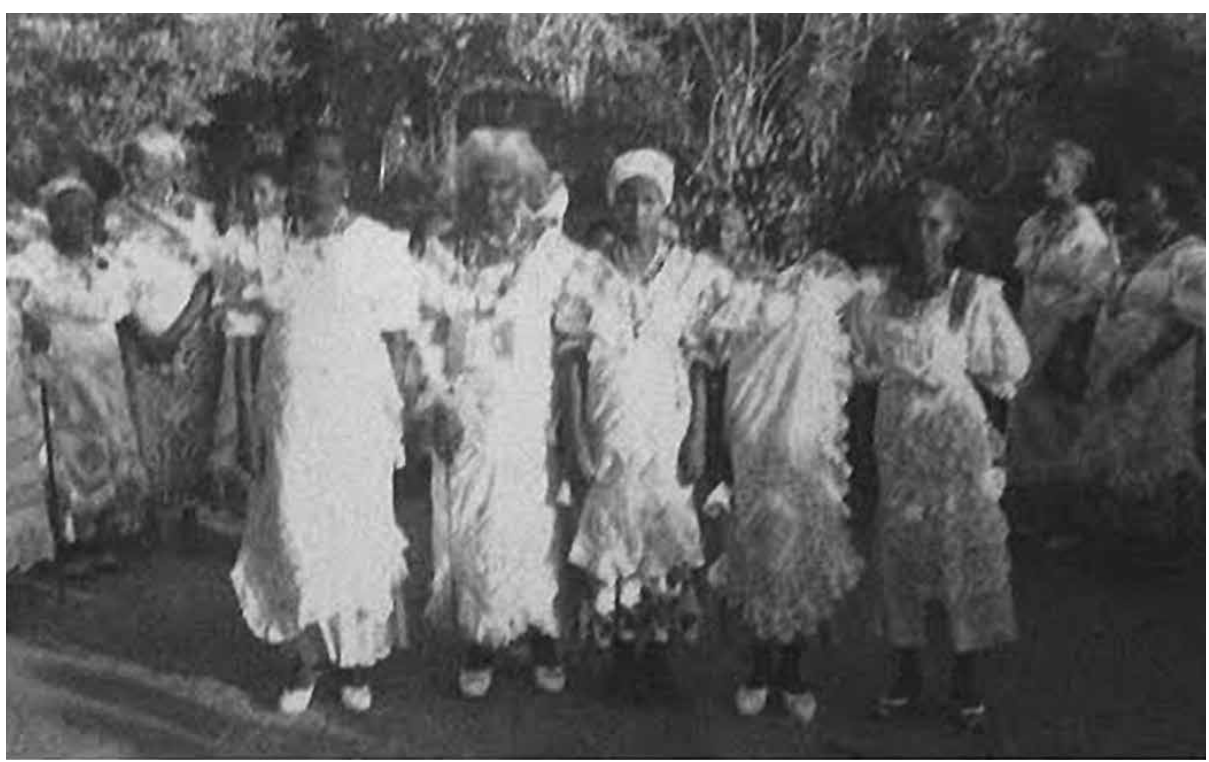

Figura 2 - Mãe-do-terreiro jeje - Mãe Andressa possuída por Poliboji - Jan. 6. 1944.

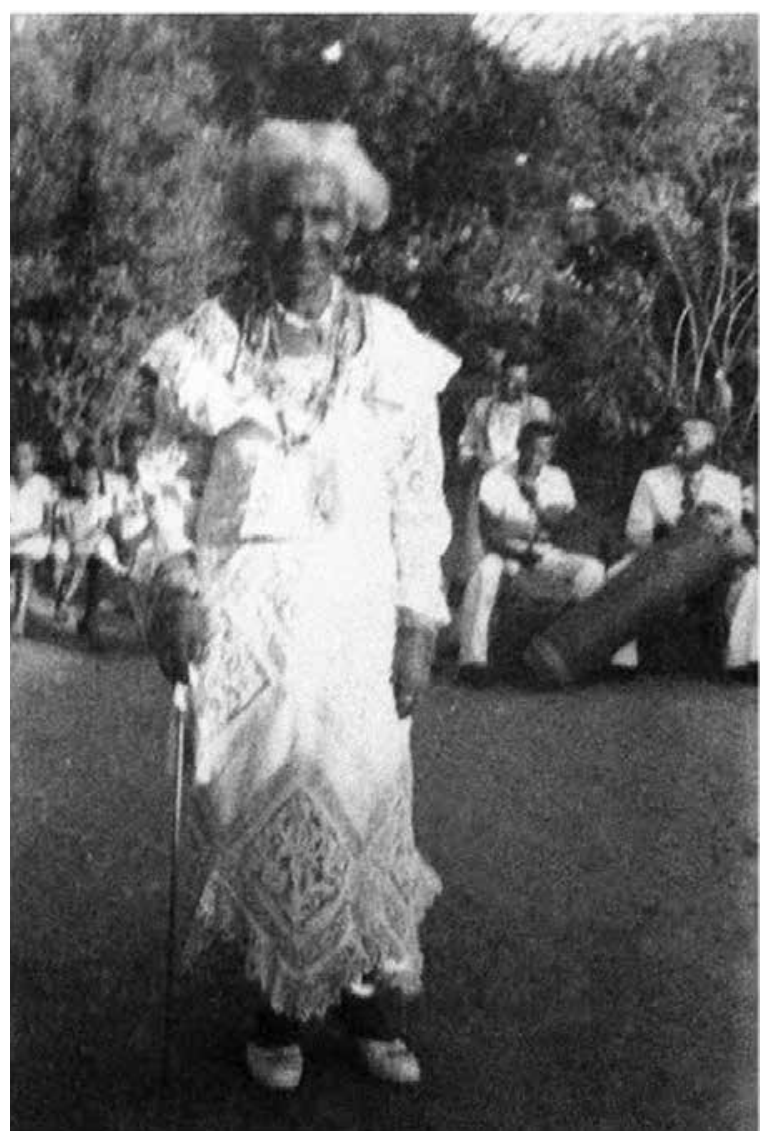




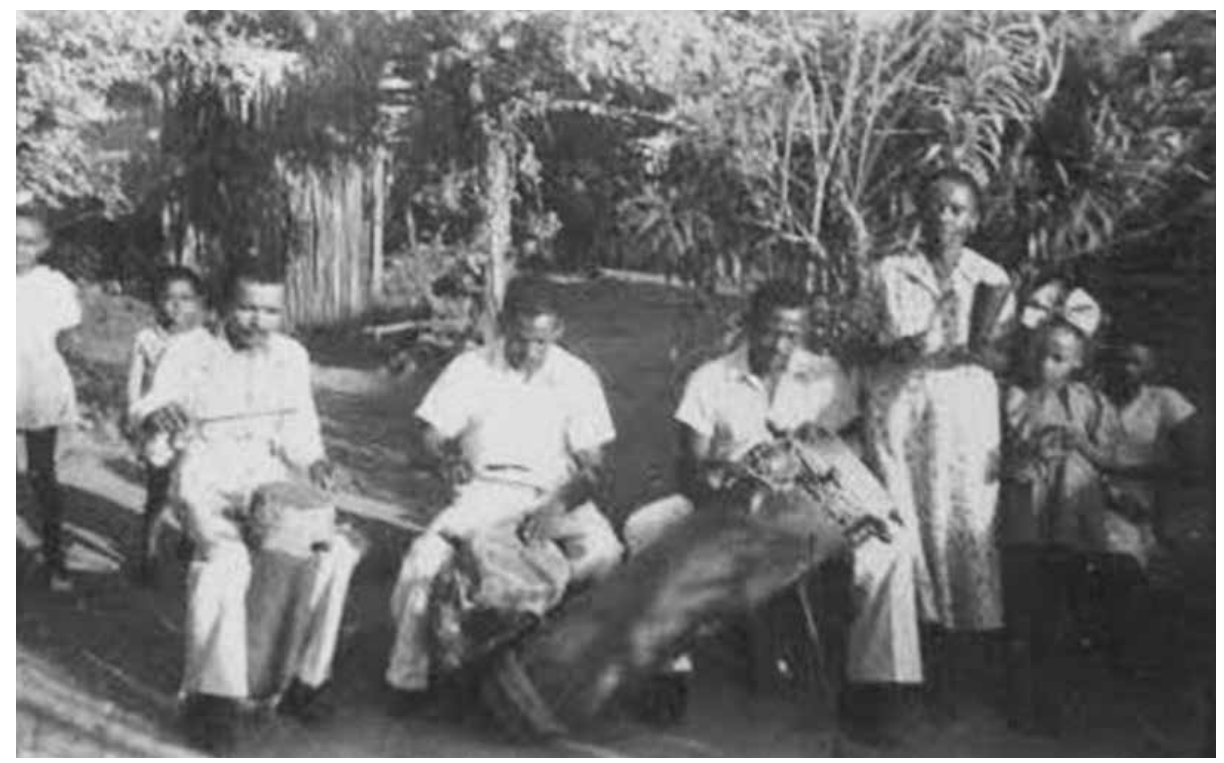

\section{Referências Bibliográficas}

CORRÊA, M. Antropólogas e Antropologia. Belo Horizonte: Editora da UFMG, 2003.

FERRETTI, S. Repensando o Sincretismo. São Paulo: EDUSP, 1995.

FRAZIER, E. F. Rejoinder to Melville J. Herskovits The negro in Bahia, Brazil: a problem in method. American Sociological Review, 8, p. 402-204, 1943.

GRUPIONI, L. D. B. Coleções e Expedições Vigiadas, os etnólogos no conselho de fiscalização das expedições artísticas e científicas no Brasil. São Paulo: HUCITEC, 1998.

HERSKOVITS, M. An outline of Dahomean Religious Belif. Memoirs of the American Anthropological Association, 41, 1933.

Pesquisas etnológicas na Bahia.

Publicações do Museu da Bahia. Salvador: Secretaria de Educação e Saúde, 1943a.
The negro in Bahia, Brazil: a problem in method. American Sociological Review, 8, p. 394-402, 1943b.

. The Southernmost Outposts of new world africanisms In: . The New World Negro. Selected Papers in Afroamerican Sudies. Indiana: Indiana University Press/Minerva Press, 1969[1943], p. 1999-216.

Drums and drummers in Afro-Brazilian cult life In: __ . The New World Negro. Selected Papers in Afroamerican Sudies. Indiana: Indiana University Press/Minerva Press, 1969[1944], p. 183-197.

MACHADO FILHO, A. da M. 0 negro e o garimpo em Minas Gerais: Rio de Janeiro: Livraria José Olympio, 1943.

RIBEIR0, R. On the Amaziado relationship, and other aspects of the family in Recife (Brazil). American Sociological Review. Official Journal of the American Sociological Society, vol. X, n 1-6, p. 44-51, 1945.

Recebido em: 26/09/16

Aprovado em: 09/11/16 